\section{ornl}

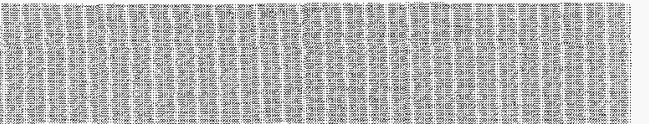

OAK RIDGE NATIONAL LABORATORY

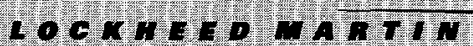

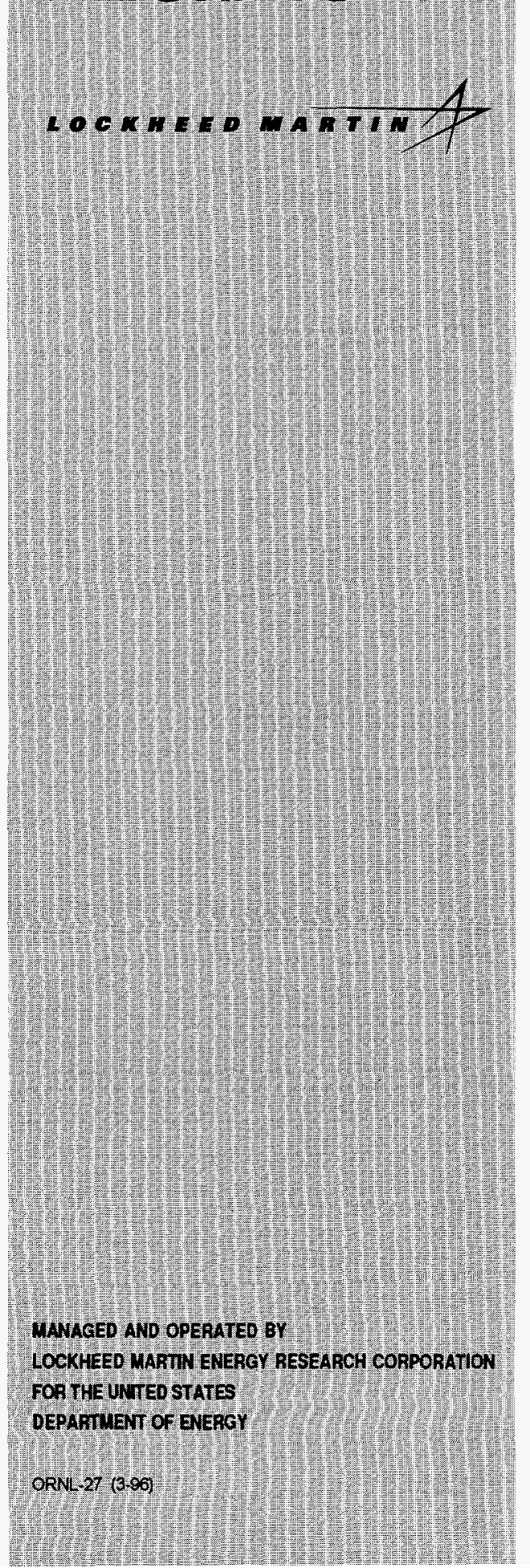
infringe privately owned rights.

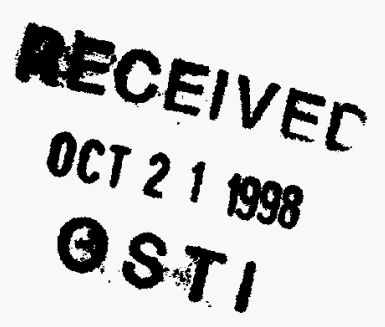

ORNL/MD/LTR-101

Level 2

\title{
Irradiated Test Fuel Shipment Plan for the LWR MOX Fuel Irradiation Test Project
}

\author{
October 16, 1998
}

\author{
L. B. Shappert \\ L. S. Dickerson \\ S. B. Ludwig
}

\section{Transportation \& Packaging Technologies Team Fissile Materials Disposition Program}

\section{NOTICE}

This report was prepared as an account of work sponsored by an agency of the United States Government. Neither the United States Government nor any agency thereof, or any of their employees, makes any warranty, expressed or implied, or assumes any legal liability or responsibility for any third party's use, or the results of such use, of any information, apparatus, product or process disclosed in this report, or represents that its use by such third party would not
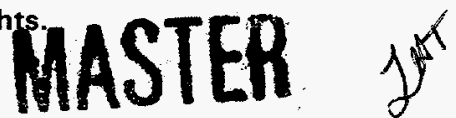
Revision History

\begin{tabular}{|c|c|l|}
\hline $\begin{array}{c}\text { Revision } \\
\text { Number }\end{array}$ & Date Issued & \multicolumn{1}{c|}{ Reason for Revision } \\
\hline 0 & $10 / 16 / 98$ & $\begin{array}{l}\text { Initial version, incorporating comments from reviews by } \\
\text { ORNL, DOE/MD, and INEEL. }\end{array}$ \\
\hline & & \\
\hline & & \\
\hline
\end{tabular}




\section{DISCLAIMER}

This report was prepared as an account of work sponsored by an agency of the United States Government. Neither the United States Government nor any agency thereof, nor any of their employees, makes any warranty, express or implied, or assumes any legal liability or responsibility for the accuracy, completeness, or usefulness of any information, apparatus, product, or process disclosed, or represents that its use would not infringe privately owned rights. Reference herein to any specific commercial product, process, or service by trade name, trademark, manufacturer, or otherwise does not necessarily constitute or imply its endorsement, recommendation, or favoring by the United States Government or any agency thereof. The views and opinions of authors expressed herein do not necessarily state or reflect those of the United States Government or any agency thereof. 


\section{DISCLAIMER}

Portions of this document may be illegible in electronic image products. Images are produced from the best available original document. 
ORNL/MD/LTR-101

Level 2

\title{
Irradiated Test Fuel Shipment Plan for the LWR MOX Fuel Irradiation Test Project
}

October 16, 1998

\author{
L. B. Shappert \\ L. S. Dickerson \\ S. B. Ludwig
}

Oak Ridge National Laboratory

Prepared by the OAK RIDGE NATIONAL LABORATORY

Oak Ridge, Tennessee 37831 managed by

LOCKHEED MARTIN ENERGY RESEARCH CORP. for the U.S. DEPARTMENT OF ENERGY under contract DE-AC05-96OR22464 


\section{TABLE OF CONTENTS}

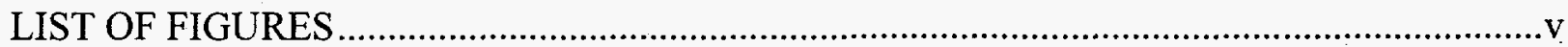

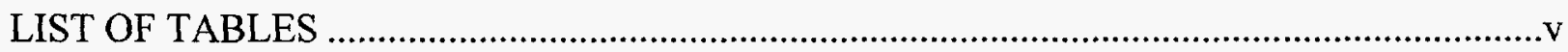

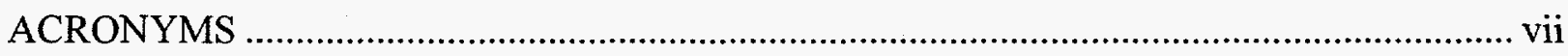

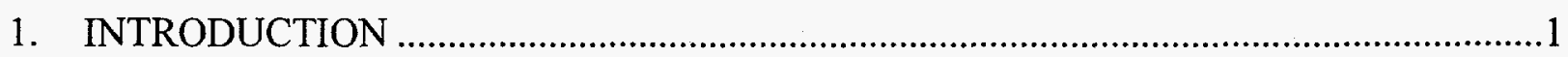

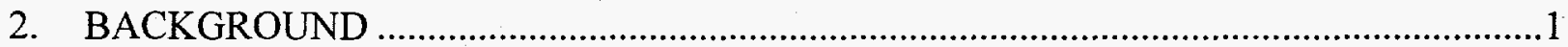

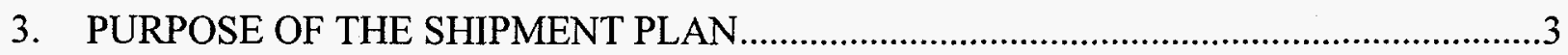

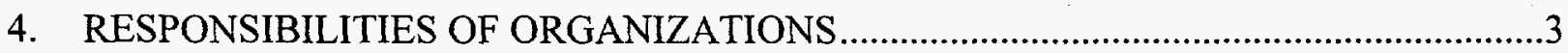

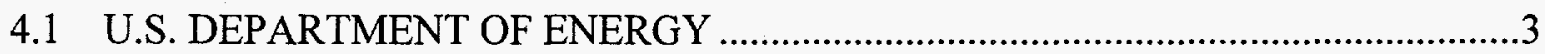

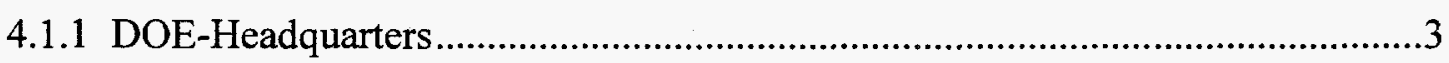

4.1.2 DOE-Idaho Operations Office ..................................................................4

4.1.3 DOE-Oak Ridge Operations Office ...........................................................4

4.2 IDAHO NATIONAL ENGINEERING AND ENVIRONMENTAL

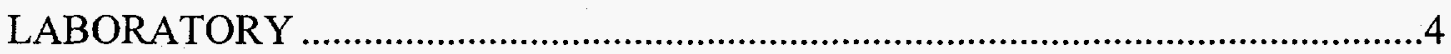

4.3 OAK RIDGE NATIONAL LABORATORY ......................................................

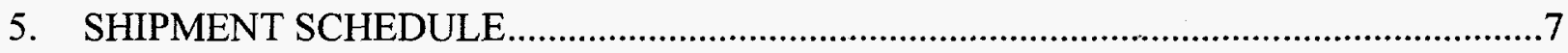

6. ADVANCE AND POST-NOTIFICATIONS AND TRACKING OF SHIPMENTS ..........10

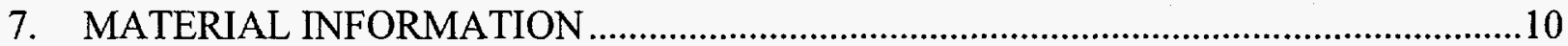

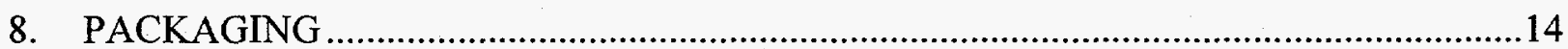

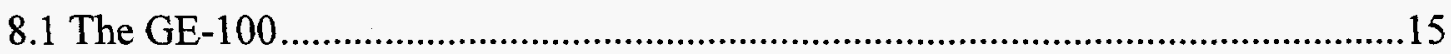

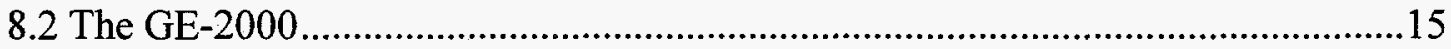

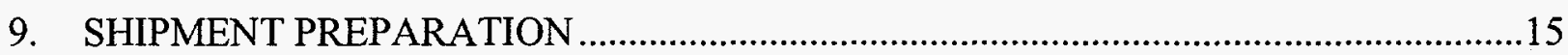

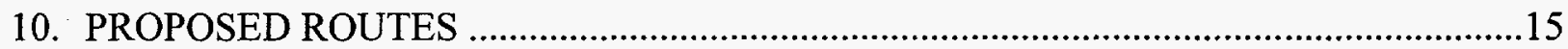

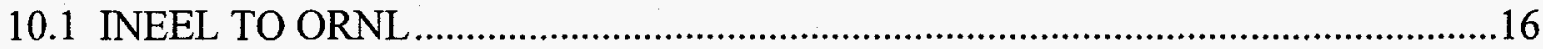




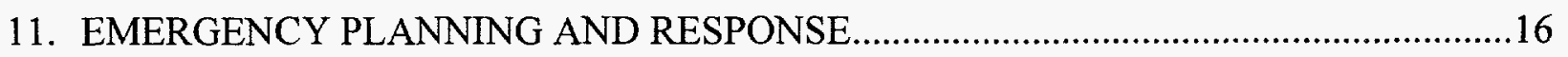

11.1 EMERGENCY PREPAREDNESS ........................................................................17

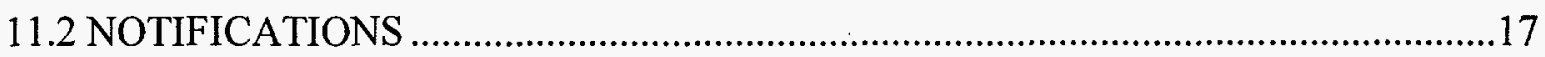

11.2.1 Carrier Breakdown.................................................................................

11.2.2 Severe Weather …….............................................................................17

11.2.3 Incident/Accident Enroute ...................................................................17

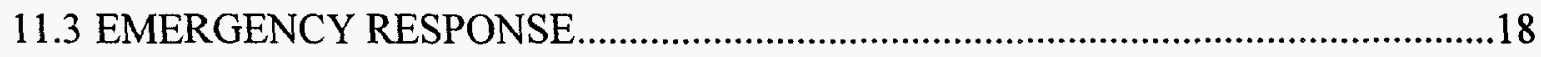

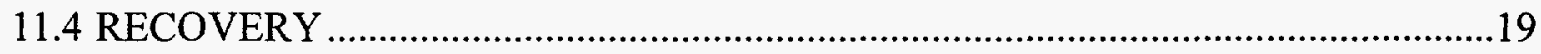

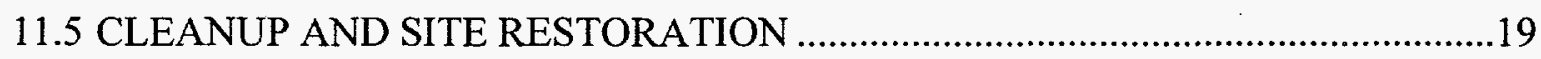

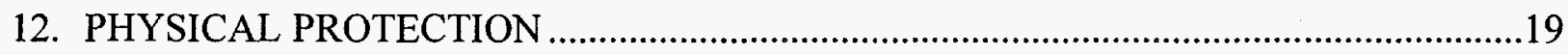

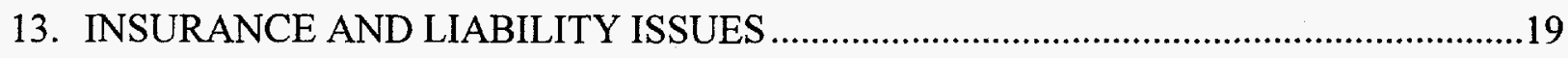

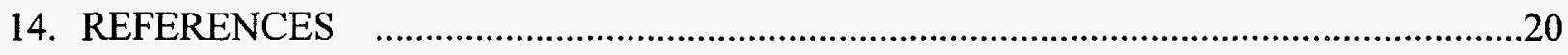

Attachment A TELEPHONE NUMBER OF DOE REGIONAL COORDINATING

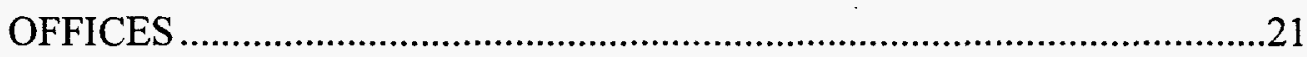

Attachment B MATERIAL ISOTOPIC ANALYSIS...........................................................25

Attachment C ROUTING ANALYSIS FOR IRRADIATED LWR MOX TEST FUEL SHIPMENT - INEEL TO ORNL …………………..................................29

Attachment D EMERGENCY RESPONSE AND RECOVERY INFORMATION ..............39 


\section{LIST OF FIGURES}

Fig. 1 Capsule and Test Assembly Configuration - Average Power Test.....................11

Fig. 2 Capsule and Test Assembly Configuration - High Power Test ........................12

Fig. 3 ATR FMDP MOX Capsule Assembly Dimensions ......................................13

Fig. C.1 Map of representative routes between INEEL and ORNL ..............................33

\section{LIST OF TABLES}

Table $1 \quad$ Average power test capsule discharge schedule ...........................................

Table $2 \quad$ High power test capsule discharge schedule ..................................................

Table B.1 Irradiated Fuel Capsule Activity - Average Power Test ................................28

Table B.2 Irradiated Fuel Capsule Actinide Composition - Average Power Test...............28

Table C.1 Summary—selected transportation routes between INEEL ..............................33

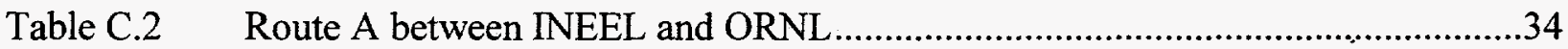

Table C.3 Route B between INEEL and ORNL ...................................................... 36 
Page Intentionally Blank 


\section{ACRONYMS}

$\begin{array}{ll}\text { ATR } & \text { Advanced Test Reactor } \\ \text { CFR } & \text { Code of Federal Regulations } \\ \text { CoC } & \text { Certificate of Compliance } \\ \text { DOE } & \text { U.S. Department of Energy } \\ \text { DOE-AL } & \text { DOE-Albuquerque Operations Office } \\ \text { DOE-EM } & \text { DOE-Environmental Management } \\ \text { DOE-HQ } & \text { DOE-Headquarters } \\ \text { DOE-ID } & \text { DOE-Idaho Operations Office } \\ \text { DOE-MD } & \text { DOE-Office of Fissile Materials Disposition Program } \\ \text { DOE-OR } & \text { DOE-Oak Ridge Operations Office } \\ \text { DOT } & \text { U.S. Department of Transportation } \\ \text { EPA } & \text { U.S. Environmental Protection Agency } \\ \text { FMCSR } & \text { Federal Motor Carrier Safety Regulations } \\ \text { GWd } & \text { giga-watt days } \\ \text { HLW } & \text { high-level waste } \\ \text { HRCQ } & \text { highway route-controlled quantity } \\ \text { INEEL } & \text { Idaho National Engineering and Environmental Laboratory } \\ \text { LANL } & \text { Los Alamos National Laboratory } \\ \text { LWR } & \text { light water reactor } \\ \text { MOX } & \text { mixed-oxide fuel } \\ \text { MT } & \text { metric ton } \\ \text { n.o.s. } & \text { not otherwise specified } \\ \text { NRC } & \text { U.S. Nuclear Regulatory Commission } \\ \text { ORNL } & \text { Oak Ridge National Laboratory } \\ \text { PIE } & \text { postirradiation examination } \\ \text { RAP } & \text { Radiological Assistance Program } \\ \text { RAT } & \text { radiological assistance team } \\ \text { RCO } & \text { Regional Coordinating Office } \\ \text { RQ } & \text { reportable quantity } \\ \text { SNF } & \text { spent nuclear fuel } \\ \text { TBq } & \text { terabecquerel } \\ \text { TI } & \text { transport index } \\ & \end{array}$


Page Intentionally Blank 


\section{INTRODUCTION}

The U.S. Department of Energy (DOE) is committed to safe, efficient, and cost-effective transportation of all materials that support its various programs and activities. DOE strives to ensure that its radioactive and other hazardous materials, hazardous substances, and hazardous and mixed wastes are handled, packaged, and transported in compliance with all applicable federal, state, tribal, and local regulations.

This document outlines the responsibilities of DOE, DOE contractors, the commercial carrier, and other organizations participating in a shipping campaign of irradiated test specimen capsules containing mixed-oxide (MOX) fuel from the Idaho National Engineering and Environmental Laboratory (INEEL) to the Oak Ridge National Laboratory (ORNL). The shipments described herein will be conducted according to applicable regulations of the U.S. Department of Transportation (DOT), U.S. Nuclear Regulatory Commission (NRC), and all applicable DOE Orders.

\section{This Irradiated Test Fuel Shipment Plan for the LWR MOX Fuel Irradiation Test Project.} addresses the shipments of a small number of irradiated test specimen capsules and has been reviewed and agreed to by INEEL and ORNL (as participants in the shipment campaign). Minor refinements to data entries in this plan, such as actual shipment dates, exact quantities and characteristics of materials to be shipped, and final approved shipment routing, will be communicated between the shipper, receiver, and carrier, as needed, using faxes, e-mail, official shipping papers, or other backup documents (e.g., shipment safety evaluations). Any major changes in responsibilities or data beyond refinements of dates and quantities of material will be prepared as additional revisions to this document and will undergo a full review and approval cycle.

\section{BACKGROUND}

DOE is supporting a demonstration program to irradiate light-water reactor (LWR) MOX fuel pins containing plutonium from surplus-weapons ${ }^{1}$ in the INEEL Advanced Test Reactor (ATR). The purpose of the program is to demonstrate many parts of this mission to dispose of surplus weapons material, including the disassembly of weapons, conversion of the plutonium metal to oxide, fabrication of MOX fuel, fabrication of fuel pins, shipment of the pins to a reactor, irradiation, postirradiation examination (PIE), and, finally, storage of the spent fuel elements awaiting eventual disposition in a geologic repository. The objective of the LWR MOX fuel irradiation tests is to burn laboratory-produced quantities of weapons-grade MOX test fuel in a test reactor under conditions approximately representative of those expected in commercial LWR reactors and then to examine the fuel pellets after irradiation. The LWR MOX fuel irradiation test project is supported by a project team, which includes DOE, Los Alamos National Laboratory (LANL), ORNL, and INEEL. 
The LWR MOX fuel irradition test project has been underway since 1996. In addition to the project plan (Ref. 1), the project team has also prepared a report that describes the expected MOX capsule loading and ATR operations schedule (Ref. 2). The shipment plan for the fresh (unirradiated) MOX fuel from LANL to INEEL was completed in September 1997 (Ref. 3). In December 1997, the initial LWR MOX fuel pins (zircaloy clad) were shipped from LANL to INEEL, thus allowing INEEL to seal the fuel pins in stainless steel capsules and insert the capsules into the ATR to commence irradiation. This test is called the "Average Power Test" or "APT".

Following insertion of the first set of Average Power Test MOX test specimen capsules in the ATR, DOE directed the project team to embark on a second, higher power LWR MOX irradiation test (Ref. 4). This test, called the "High Power Test" or "HPT" would be operated at a higher specific power than the previous irradiation test and would irradiate the MOX fuel test specimen capsules to a greater burnup level. Like the APT, the MOX capsule loading and ATR operations schedule was documented by letter report (Ref. 5). The HPT project plan schedule indicates that the first HPT MOX fuel should begin irradiation in February 1999.

Based on the capsule loading and ATR operation schedules (Refs. 2 and 5), groups of APT and HPT irradiated MOX test specimen capsules will be discharged, and these irradiated capsules will be shipped from INEEL to ORNL to undergo PIE. ORNL and INEEL have the following major responsibilities with regard to the shipment of the irradiated test specimen capsules:

1. ORNL has the lead responsibility for overall project coordination as part of the Reactor Project of the DOE Fissile Materials Disposition Program. To this end, ORNL has developed the pellet and pin specifications, designed and fabricated the irradiation basket, fuel pins, and capsules, predicted the test fuel behavior, and determined the ultimate burnup for the test fuel pins. Once the capsules have been irradiated, ORNL will coordinate with INEEL to ensure the packages chosen to ship the test specimens are compatible with ORNL facilities; ORNL will receive the shipments containing the irradiated test capsules, disassemble the capsules, perform the PIE, package and dispose of the waste materials generated in the PIE, and report the test results.

2. INEEL has the lead responsibility for ensuring that the tests are designed and operated in compliance with all safety and regulatory requirements. INEEL provided specifications, drawings, reactor data, and other guidance, as required, to ORNL to ensure that the design of the test specimens met the requirements of the ATR; is conducting the irradiation of the test specimens; will remove test specimens at prescribed burnups; and will be responsible for the packaging, safeguards and security, emergency planning, notifications, and transportation to ORNL of the irradiated test capsules. 


\section{PURPOSE OF THE SHIPMENT PLAN}

In consideration of the sensitivity and importance of this program, the DOE-Headquarters Office of Fissile Materials Disposition (DOE-MD), as the program office for the LWR MOX test fuel irradiation test project, has mandated a shipment plan for the irradiated test-fuel transport from INEEL to ORNL. This document, The Irradiated Test Fuel Shipment Plan for the LWR MOX Fuel Irradiation Test Project, will satisfy that requirement.

This Shipment Plan describes the responsibilities of all parties to the transportation functions and contains information describing material types, approximate shipping schedules, estimated number of shipments, modes of transport, proposed routes, packaging descriptions, emergency response, and any security arrangements that might be needed.

\section{RESPONSIBILITIES OF ORGANIZATIONS}

The complexity of the LWR MOX fuel irradiation test project and the number of supporting organizations mandate that all roles and responsibilities be clearly defined and observed throughout the life of the project. Each phase of the demonstration program has its own planning effort. This document addresses only the responsibilities unique to the transportation phase of irradiated capsules from INEEL to ORNL. The transportation-related responsibilities of the parties are defined below.

\subsection{U.S. DEPARTMENT OF ENERGY}

\subsubsection{DOE-Headquarters (Office of Fissile Materials Disposition - DOE-MD)}

The DOE-MD establishes the overall policy for transporting project materials, resolves policy questions, issues guidance, and provides information to use in transportation activities. DOE$\mathrm{MD}$ is responsible for seeking and for arranging funding authority for DOE laboratories and for arranging procurement authorization for other parties.

DOE will provide emergency response teams, including personnel with packaging operations, radiological, and transportation management expertise in the event of a transportation incident or accident. Such assistance is provided by Headquarters, on the request of the state or local emergency response teams, through the DOE Regional Coordination Offices (RCOs). (The two area offices involved in these shipments are the Oak Ridge and Idaho RCOs. A list of all DOE RCOs is provided in Attachment A.) 


\subsubsection{DOE-Idaho Operations Office (DOE-ID)}

DOE-ID is responsible for overall program management for the transfer of irradiated LWR MOX fuel test specimen capsules from INEEL to ORNL. DOE-ID is the shipper of record, and INEEL acts as the agent. DOE-ID has the following responsibilities:

- Approving the shipment of the irradiated test specimen capsules from INEEL to ORNL. The DOE-ID Transportation Program Manager [Miriam R. Taylor, (208) 526-0176] shall have oversight responsibility to ensure that the shipment is conducted in compliance with federal regulations, DOE Orders, and DOE-ID policies.

\subsubsection{DOE-Oak Ridge Operations Office (DOE-OR)}

DOE-OR is responsible for activities conducted at ORNL, which include receipt of the irradiated test specimen capsules and conduct of the PIE. The DOE-OR Traffic Manager is P. B. Lester (423) $576-8354$.

\subsection{IDAHO NATIONAL ENGINEERING AND ENVIRONMENTAL LABORATORY}

Items for which INEEL is responsible related to the shipment of irradiated test specimen capsules from INEEL to ORNL are described below.

- Procuring packaging, certified for carrying the appropriate quantities of irradiated MOX, in which to ship the irradiated test specimen capsules and loading the packaging with the irradiated test specimen capsules. The shipment shall meet all applicable DOE and DOT regulations.

- $\quad$ Staging the packaging with adequate time such as to allow for inspection and loading before the scheduled shipping date. All preloading activities (e.g., preparing and testing the loading equipment, preparing procedures for compliance, and scheduling of required support personnel) are the responsibility of INEEL.

- Selecting the carrier. It is preferred, although not required, that the carrier selected be evaluated according to DOE's Motor Carrier Evaluation Program Plan and Procedures (Ref. 6).

- Coordinating the schedule for loading and shipping the material with ORNL. The actual schedule will be based on factors such as INEEL's capability to load and ship materials, ORNL's ability to receive the material, predicted weather conditions, and existing road conditions along the route. Should the shipment arrival at ORNL occur outside of normal business hours, INEEL and/or the carrier's dispatch center should contact the ORNL Laboratory Shift Superintendent (LSS) at (423) 574-6606 to arrange access to the ORNL site. 
- Making the preshipment notifications, preferred routing information using DOE-approved routing methods (e.g., the ORNL HIGHWAY code), and shipment schedule and updates to the DOE Prospective Shipment Module, DOE-ID, carrier, DOE-OR and ORNL. The notice to ORNL will request authorization to ship on the expected date, will provide a time of expected arrival, name of carrier, and transport identification. Official notification and authorization request will be made to the ORNL Traffic Manager [C. E. Elben, (423) 5747014, FAX (423) 576-1979]. As a courtesy, INEEL may provide additional notifications of the shipment to: Bldg. 3525 Facility Manager [C. E. DeVore, (423) 576-7713], PIE project manager [R. N. Morris, (423) 241-4237], and the Lockheed Martin Transportation \& Packaging Management organization [S. D. McGhee (423) 574-7114].

- Ensuring that radioactive contamination and radiation levels for the package and vehicle are in compliance with the U.S. regulations, through surveys performed on loaded packages and vehicles by qualified, trained personnel using calibrated equipment and following approved procedures.

- $\quad$ Ensuring that all shipping documentation is properly completed, signed, and certified and that all required labeling, marking, and placarding complies with DOT's Hazardous Materials Regulations (49 CFR Parts 171-180) before release of the shipment.

- Providing fissile material quantity information on the appropriate nuclear material transfer form [Form 741]. At ORNL, contact either R. N. Morris at (423) 241-4237 or P. McGill [ORNL Nuclear Material Accountability group, (423) 574-7022].

- $\quad$ Providing the carrier driver with an information packet containing copies of the shipping papers, emergency response information, and special instructions for the shipment before the shipment is dispatched from INEEL.

- Ensuring that the motor carrier is in compliance with the FMCSR (49 CFR Parts 350 399). INEEL will verify the carrier's qualifications, including, but not limited to, driver's qualifications and carrier's equipment, insurance, and state permits, as necessary.

- Approving the carrier's route before shipment and with the prior concurrence of ORNL.

- Ensuring that the motor carrier's vehicle is in compliance with FMCSR, Appendix G, "Minimum Periodic Inspection Standards," (Ref. 7) before loading and that the load is properly secured prior to departure.

- Ensuring receipt of confirmation from ORNL, prior to shipment, that ORNL is prepared to receive the shipment at the planned time and location. The shipment will arrive on the ORNL site at the central receiving area of Bldg. 7001. The ORNL Traffic Manager [C. E. Eblen, (423) 574-7014] should be contacted to confirm that ORNL is prepared to receive the shipment from INEEL. 
- Meeting the physical protection requirements for transport of this material according to DOE and NRC regulations.

INEEL shall ensure that the selected carrier, under contract to INEEL, meets its responsibilities for safely transporting the irradiated LWR MOX fuel test specimen capsules from INEEL to ORNL. The selected carrier of each shipment has the following responsibilities:

- Installing and properly maintaining the "RADIOACTIVE" placards on the trailer.

- Obtaining required permits and arranging for vehicle inspections along the transportation route, as required by INEEL. (Where practicable, the carrier will work with all regulatory bodies to arrange inspections, as necessary. The carrier will notify the appropriate state vehicle inspection agencies to arrange for vehicle inspections.)

- $\quad$ Providing emergency recovery personnel, equipment (including repair and replacement of tractor or trailer, as necessary), and for procedures in the event of an incident. The carrier has primary responsibility for cleanup and site restoration in the event of an accident.

- $\quad$ Ensuring that: (1) driver training requirements have been met, (2) vehicles meet FMCSR, Appendix G(Ref. 7) inspection requirements before the vehicle is placed in service, (3) vehicles en route satisfy the Commercial Vehicle Safety Alliance Out-of-Service (Ref. 8) criteria, and (4) all other FMCSRs are met.

- Maintaining communication with INEEL via the carrier's dispatch center from departure from INEEL to arrival at ORNL. Any deviation in approved shipment routing, expected arrival times, or unplanned stoppages will be reported to the carrier dispatch center and, through that center, to INEEL, ORNL, and DOE-MD.

- $\quad$ Ensuring that its dispatch center will provide effective communication with the drivers on all extraordinary events involving the shipment, including all known external public relations events that could impact the shipment.

\subsection{OAK RIDGE NATIONAL LABORATORY}

ORNL, which is the lead laboratory for reactor alternatives for fissile materials disposition, is managing the program for DOE-MD. ORNL is responsible for receiving the irradiated test specimen capsules, disassembling these capsules, performing the PIE, developing the data and other information from the PIE and submitting it to DOE, and disposing of the waste from the examination. 
Items for which ORNL is responsible that relate to the shipment of the irradiated test specimen capsules from INEEL to ORNL are the following:

- Preparing the irradiated test fuel shipping plan (this document)

- Notifying INEEL of acceptance of INEEL-prepared shipping schedule and details.

- Coordinating with INEEL to ensure that the shipping packages chosen by INEEL are compatible with the central receiving facilities at ORNL (Bldg. 7001). ORNL will also arrange for the on-site movement of the package from the ORNL central receiving facility to the PIE facility (Bldg. 3525). C. E. DeVore is Facility Manager of Bldg. 3525 [(423) 5767713]. R. N. Morris is project manager in charge of the PIE activity [(423) 241-4237]. Packaging compatibility questions should be directed to either C. E. Eblen, R. N. Morris, or to S. D. McGhee [Lockheed Martin Transportation \& Packaging Management, (423) 5747114].

- Notifying INEEL immediately upon receipt of material or if there is a delay past the estimated time of arrival or a suspected loss of material.

- Preparing and arranging for transport of the empty shipping package back to INEEL or to another location specified by INEEL.

- Ensuring that radioactive contamination and radiation levels for the empty package and the vehicle are in compliance with the U.S. regulations, through surveys performed on loaded packages and vehicles by qualified, trained personnel using calibrated equipment and following approved procedures.

- Preparing the empty package for return to the custodian at GE Vallecitos Nuclear Center in Pleasanton, California. ORNL will arrange for a separate carrier to transport the empty package back to GE Vallecitos [the custodian at GE Vallecitos is Erin Heinlein (925) 8624567]. ORNL will provide the carrier driver with an information packet containing copies of the shipping paper, emergency response information, and special instructions before the shipment of the empty cask is returned.

\section{SHIPMENT SCHEDULE}

This report covers the shipments of the test specimens that have been irradiated as part of the Average Power Test (APT) program and the High Power Test (HPT) program in the ATR.

Average Power Test Shipments. In the case of the APT program, a total of 11 MOX capsules have been or will be inserted in the reactor and will be discharged at three different times (Ref. 2) and sent to ORNL for a PIE; varying the discharge dates will have the effect of varying the 
burnup in the capsules from approximately 8 to $30 \mathrm{GWd} / \mathrm{MT}$. Table 1 identifies the number of capsules that will be discharged, projected discharge dates, and the expected burnup of those capsules as part of the average power test irradiation schedule.

Table 1: Average Power Test Capsule Discharge Schedule ${ }^{2}$

\begin{tabular}{|c|c|c|}
\hline No. of MOX Capsules Discharged & Projected Discharge Date & Average Burnup, GWd/MT \\
\hline 2 & Sept. 1998 & 8 \\
\hline 2 & Dec. 1999 & 20 \\
\hline 7 & Jan. 2001 & 30 \\
\hline
\end{tabular}

Note: The table above only lists the MOX capsules from each phase of the average power test. Phase III also includes "dummy" capsules that will be shipped with the Phase III MOX capsules to ORNL.

Each set of capsules will be shipped to ORNL in one of three separate shipments shortly after discharge from the ATR. The exact cooling time between when the capsules are discharged and then shipped to ORNL is not fixed, but is expected to be about 30 days. Shielding and heat transfer requirements have been examined for capsules shipped as short as 7 days after discharge. 
High Power Test Shipments. In the case of the HPT program, a total of 13 MOX capsules will be inserted in the reactor and will be discharged at three different times (Ref. 5) and sent to ORNL for a PIE; varying the discharge dates will have the effect of varying the burnup in the capsules from 15 to $45 \mathrm{GWd} / \mathrm{MT}$. As in the APT Program, Table 2 identifies the number of capsules that will be discharged, projected discharge dates, and the expected burnup of those capsules. And similar to the APT Program, three shipments of HPT capsules are planned to transfer these irradiated capsules to ORNL.

Table 2: High Power Test Capsule Discharge Schedule ${ }^{5}$

\begin{tabular}{|c|c|c|}
\hline No. of MOX Capsules Discharged & Projected Discharge Date & Average Burnup, GWd/MT \\
\hline 4 & Dec. 1999 & 15 \\
\hline 1 & Sept. 2000 & 30 \\
\hline 8 & Jul. 2001 & Four at 30; Four at 45 \\
\hline
\end{tabular}

Note: The table above only lists the MOX capsules from each phase of the high power test. The high power test will also include irradiated control capsules (low-enriched uranium) that will be shipped to ORNL.

Note that at the end of the third cycle of the HPT, eight MOX capsules will be discharged, half of which will have reached an average burnup of about $30 \mathrm{GWd} / \mathrm{MT}$ and half that will have achieved an average burnup of about $45 \mathrm{GWd} / \mathrm{MT}$. All eight capsules will be shipped together to ORNL in one cask.

Each set of capsules will be shipped to ORNL shortly after discharge from the ATR. The exact cooling time between when the capsules are discharged and subsequently shipped to ORNL is not fixed, but is expected to be about 30 days.

It may be possible, assuming that the ATR irradiations occur as planned, to combine one or more of the irradiated test specimen capsule shipments into a single shipment. Based on the present planned schedules, the discharge of the $2^{\text {nd }}$ irradiation cycle APT coincides with the discharge of the $1^{\text {st }}$ irradiation cycle HPT.

The estimated travel time for the shipment from INEEL to ORNL is about 34 hours, assuming legal speeds are maintained on highways (see appendix $C$ ). Actual shipment time will vary somewhat because of required stops, delays enroute, vehicle servicing, inclement weather, and carrier inspections. 


\section{ADVANCE AND POST-NOTIFICATIONS AND TRACKING OF SHIPMENTS}

Advance notification to the states is not required for these shipments. However, for the irradiated test capsule shipments, INEEL will provide ORNL with advance notification.

The carrier will notify its dispatch center of any unscheduled stops enroute, including stops for inclement weather. Any deviation from the preferred route chosen will comply with applicable state, tribal, and local regulations, and carrier operating procedures.

For the irradiated test capsule shipments, ORNL will notify INEEL (1) on receipt of material, (2) if the shipment has not arrived on time (by end of 1st working day past shipment due date), or (3) if the material is suspected to be lost or otherwise unaccounted for.

\section{MATERIAL INFORMATION}

The test fuel pins are composed of high-density, sintered, MOX pellets. The pellets were manufactured by LANL from depleted uranium oxide and plutonium oxide according to the technical specifications document (Ref. 9). The pins for the APT consist of zircaloy-tube cladding, with $15 \mathrm{MOX}$ pellets each, and welded end-caps. The pins were then encapsulated in stainless steel tubes with welded-end caps by INEEL before their insertion into the ATR. For the HPT, the pins consist of zircaloy-tube cladding, with 13 MOX pellets each and an upper and lower hafnium-oxide shield pellet, and welded-end caps. The HPT pins, when fabricated, will also be encapsulated in stainless steel tubes with welded-end caps by INEEL before their insertion into the ATR. Figures 1 and 2 shows the configuration of the capsule and test assembly for the APT and the HPT, respectively. Figure 3 shows a detailed view of a "typical" capsule assembly for the APT, with representative dimensions. 
ORNL-DWG 97-2775 EFG

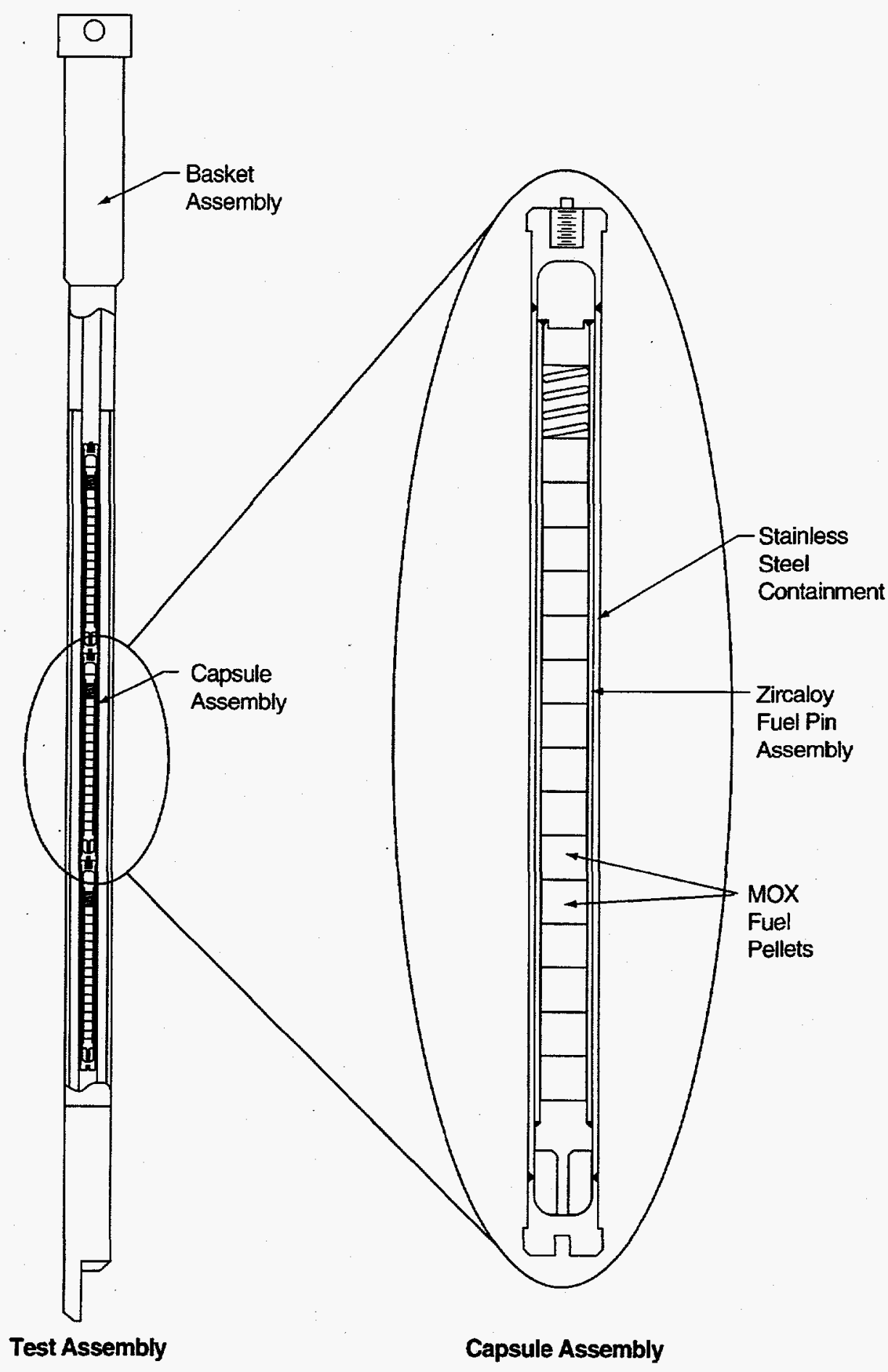

Figure 1. Capsule and Test Assembly Configuration - Average Power Test 
ORNL 98-2219 EFG

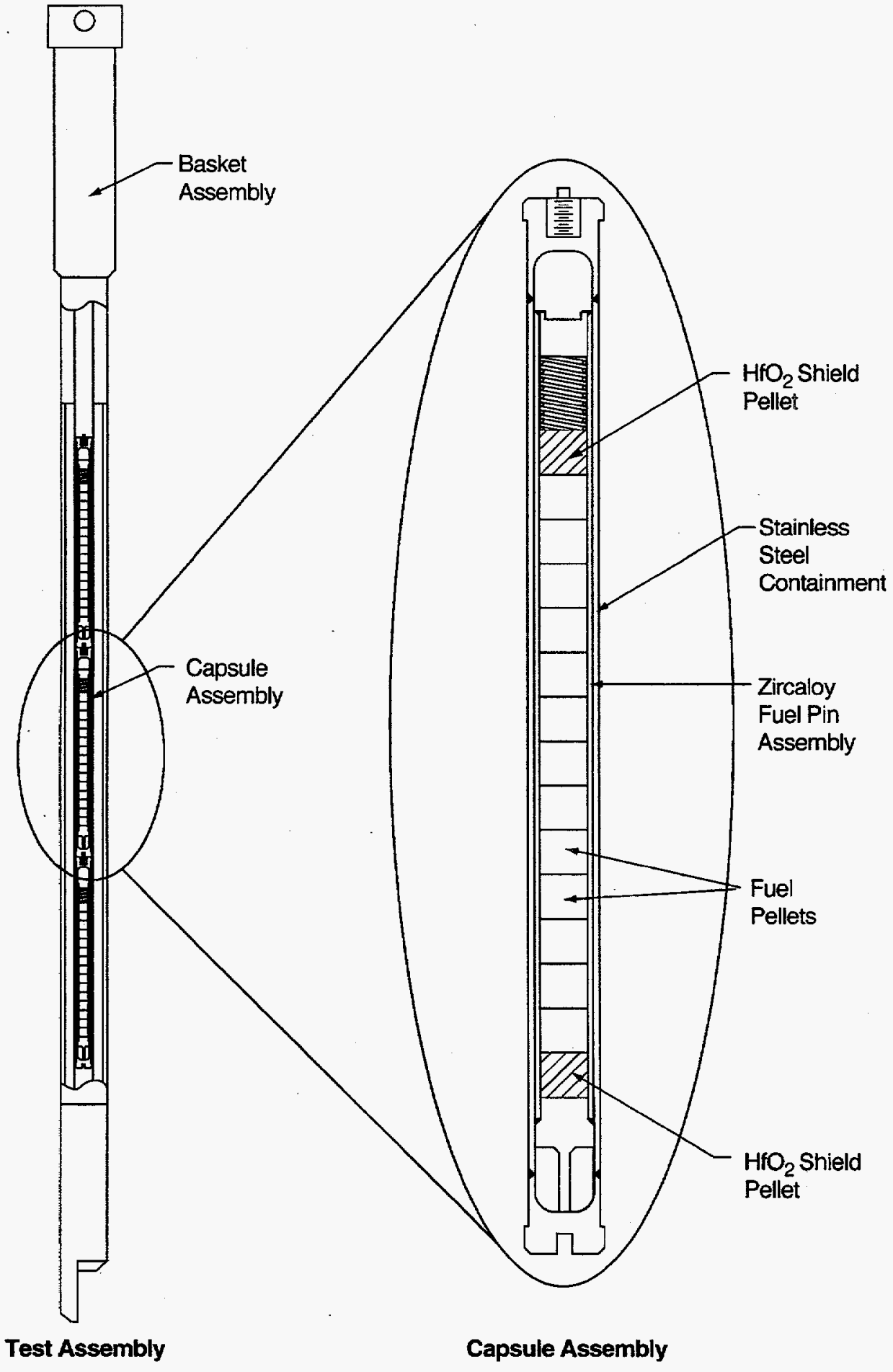

Figure 2. Capsule and Test Assembly Configuration - High Power Test 


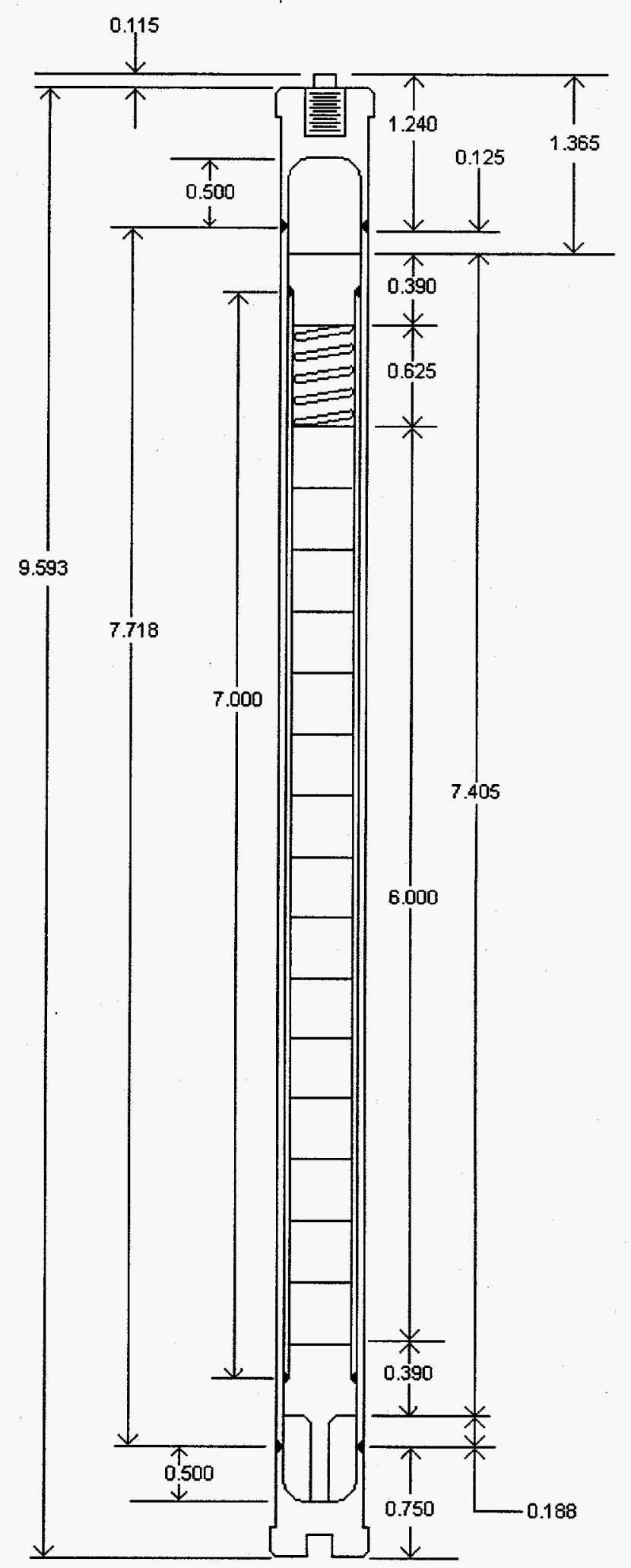

Figure 3. ATR FMDP MOX Capsule Assembly Dimensions 
Upon discharge from the ATR, each capsule will contain fewer grams of fissile material than when it was inserted, but will contain the fission products that were produced during the irradiation cycle and additional radioactivity due to the neutron activation of the non-fuel components of the MOX capsules (i.e., activation products in the zircaloy and stainless steel structural components). Decay of the actinides, fission products, and activation products produces photons, neutrons, and heat. All decay products have been identified and evaluated.

The thermal output from each capsule is small, generally less than 3 watts after 30 days decay. The penetrating radiation (both photons and neutrons) has been examined, using the ORIGEN-S code, for capsules discharged after each irradiation cycle. Using information generated from the ORIGEN-S code, all significant fission products were considered and evaluated as a function of time after discharge. This information provides the foundation for (a) identifying the radiation source terms for the capsules as a function of time after discharge, (b) determining the proper shielding required to protect workers during handling operations, and (c) evaluating the various packagings that may be used to transport the capsules from INEEL to ORNL.

The activity of the activation products, actinides, and fission products are summarized in Appendix B. Also presented are the quantities of the uranium and plutonium isotopes after irradiation.

Note that the activity for each isotope may change for each shipment depending on the level of irradiation and the actual cooling time between reactor shut down and when the shipment is made. The correct (or maximum) activity for the most significant isotopes being shipped will be provided on the official shipping papers.

\section{PACKAGiNG}

The irradiated capsules that will be shipped from INEEL to ORNL contain sufficient quantities of actinides and fission products to exceed Type A limits. Thus, the packaging chosen to ship the material must be a Type B package and have a current Certificate of Compliance (CoC) approved for transporting these types of materials. The choice of packages is the responsibility of INEEL. The packaging must have adequate shielding and sufficient cavity size to accommodate the capsules as they will be shipped.

Two shipping casks are considered candidates for transporting the irradiated fuel capsules to ORNL from INEEL: these are most probably the GE-100 with the GE-2000 as a backup. These packagings are briefly described below. For either candidate package, a simple "handling container" will need to be fabricated to function as a dunnage/shoring to secure and protect the irradiated test specimen capsules during shipment.

INEEL will be responsible for supplying a suitable "handling container" and in acquiring a suitable packaging for the shipment. In the case of the GE-100 or GE-2000, use of the packages is arranged by rental agreement with the GE Vallecitos Nuclear Center in Pleasanton, California. 
ORNL will be responsible for preparing and returning the empty package to GE in a timely manner after each shipment and for returning the empty handling container to INEEL after each shipment.

\subsection{THE GE-100 CASK}

The GE-100 cask (CoC 5926) is a steel-shelled, lead-shielded shipping cask approximately $20 \mathrm{in}$. in diameter and 27 in. tall; it weighs about $4,800 \mathrm{lb}$ and has a central cavity $75 / 8 \mathrm{in}$. in diameter by $10 \mathrm{in}$. high. The package has $57 / 8 \mathrm{in}$. of lead shielding surrounding the cavity, and is designed to allow additional shielding in the cavity, if necessary. The cask is certified to transport irradiated fuel rods. The certification has a current expiration date of May 31, 2003.

\subsection{THE GE-2000 CASK}

The GE-2000 cask (CoC 9228) is a steel-shelled, lead shielded shipping cask, approximately $38.5 \mathrm{in}$. in diameter and $71.0 \mathrm{in}$. in height; it has a central cavity that is $26.5 \mathrm{in}$. in diameter and 54.0 in. deep; it is certified to transport irradiated fuel rods and fuel assemblies (including HFIR spent cores). Shielding consists of the two 1 in. steel shells and 4 in. of lead surrounding the cavity. The cask has a toroidal energy absorber attached to both its top and bottom. The gross weight of the package is $33,550 \mathrm{lb}$. The certification has a current expiration date of June 30 , 1999.

\section{SHIPMENT PREPARATION}

In addition to observing the proper packaging procedures for the shipping container, INEEL is responsible for preparing the shipping papers, ensuring that the marking and labeling are correct, and supplying the proper placards to the carriers. The carrier is responsible for attaching the placards, as is required by DOT.

\section{PROPOSED ROUTES}

All shipments of irradiated test specimen capsules made from INEEL to ORNL in this campaign will be by highway. Two representative routes have been calculated for each shipment using the software program called HIGHWAY, which was developed by DOE specifically to select routes for shipments of radioactive materials using criteria set forth in U.S. DOT regulations. The two representative routes are briefly described below and in more detail in Attachment $\mathrm{C}$. The two routes, designated Route A and Route $\mathrm{B}$, have been identified as the most direct routes between INEEL and ORNL. Both routes may also be considered as "preferred" routes, as these meet the U.S. DOT regulations should the shipment quantity be sufficiently large to invoke a Highway Route Controlled Quantity (HRCQ) designation. INEEL, as the shipper, will be responsible for determining if the shipment quantity must be HRCQ-designated, and will, working with the carrier, select the actual route to be used for each shipment, in compliance with applicable 
regulations. Should the shipment be less than a HRCQ, the actual route used will be a typical route used by the carrier for INEEL-to-ORNL shipments. The actual shipment route will be specified in the final arrangements among INEEL, the carrier, and ORNL.

\subsection{INEEL TO ORNL}

A. The Route A is 27 miles longer than the Route B, but takes about one half hour less driving time, based on the legal highway speed limits along each route segment. Route A goes south on I-15 to Utah joining I-84, and then turns southeasterly and connects with I-80 to proceed east from Utah through Wyoming and Nebraska (with a deviation around Omaha) to I-29. It then follows I-29 south through southwestern Iowa and northwestern Missouri, circumventing the Kansas City area to access I-70 and follows it to St. Louis, Missouri. Circumventing the city of St. Louis, it proceeds southeastward to Mt. Vernon, Illinois, and then south via I-57 to I-24 at Pulleys Mill, Illinois. The route then follows I-24 through Paducah, Kentucky, to Nashville, Tennessee, and then proceeds eastward to Oak Ridge, Tennessee, by I-40 and State 95 .

B. The alternative route (Route B), although shorter than Route A, takes additional driving time due to slower driving times around Denver and lower speed limits in Kansas. Route B follows the same path from INEEL to Laramie, Wyoming, where it proceeds south on I-25 to Denver, Colorado. At Denver, it forks easterly onto I-76 and then I-270 before joining I70 and proceeds through eastern Colorado and Kansas. Near Kansas City, Kansas, it follows I-435 around the southern part of the metropolitan area. Southeast of Kansas City, Missouri, it rejoins the preferred route and follows the same path to ORNL.

The actual shipment route will be specified in the final arrangements between INEEL and ORNL. The carrier will be provided the exact route by INEEL prior to the final shipment approval.

\section{EMERGENCY PLANNING AND RESPONSE}

State, tribal, and local government officials are responsible for emergency response to any accident within their jurisdictions. Initial responders administer first aid, isolate the area; attempt to identify the hazard, and notify appropriate state and federal authorities. Federal agencies respond to an emergency when specifically requested to do so by the state, tribal, or local government officials. DOE is the primary agency for providing radiological monitoring and assessment assistance. DOE's support ranges from giving technical advice by telephone to sending highly trained personnel and equipment to the accident site to help identify and minimize any radiological hazards. The carrier of the shipment is responsible for providing emergency response assistance and recovery and restoration actions, as necessary. 


\subsection{EMERGENCY PREPAREDNESS}

As the DOE-designated shipper, INEEL will provide shipper-related emergency information and maintain a 24-h emergency telephone contact for technical advice and detailed information regarding the shipment. This telephone number is recorded on the shipping papers that accompany the shipment.

\subsection{NOTIFICATIONS}

\subsubsection{Carrier Breakdown}

The carrier driver will notify the dispatch center when mechanical problems have been encountered or if a driver is incapacitated. If assistance and replacement equipment or drivers are needed, the carrier dispatch center will notify the shipper. Information pertaining to the vehicle breakdown shall be noted in the carrier dispatch center's log. If the vehicle must deviate from the preferred route for vehicle repair or any other condition that makes continued use of the preferred route unsafe, the dispatch center will notify the shipper that the vehicle will be deviating from the preferred route. INEEL will notify ORNL of any delay resulting from driver or mechanical problems. The INEEL Packaging and Transportation Manager is M.D. Ruska, (208) 526-2414. The ORNL Traffic Manager is C. E. Eblen (423) 574-7014.

\subsubsection{Severe Weather}

Severe weather information can be obtained from numerous sources. Upon indication of severe weather, the carrier dispatch center shall notify the driver and obtain the driver's input (if not initially alerted to the weather conditions by the driver). The center will then obtain further information from the state police of the affected states, and either:

- divert the driver, truck, and cargo to a state-designated safe parking haven until weather improves;

- direct the driver to remain at the present location until weather conditions permit safe travel; or

- delay the shipment, if driver has not left the shipper's facility, until weather improves.

Details of the decisions of the carrier dispatch center will be entered into the dispatch center log.

\subsubsection{Incident or Accident Enroute}

In the event of an incident or accident, the driver will notify the 911 line, the appropriate state patrol, and the carrier dispatch center of the event. If the driver is unable to respond, the carrier dispatch center will notify the state patrol that the driver is not responding. The state patrol can then locate the truck and establish an incident command center, if necessary. Following the alert 
of the local officials, the driver or the carrier dispatch center will contact the shipper's 24-h emergency notification number [phone (208) 526-1515].

Any state, tribal, local, or private sector organizations needing radiological assistance can call the nearest DOE RCO to obtain information, advice, or assistance. The DOE Regional Coordinator decides what action is needed based upon the request. Following initial contact, the DOE RCO also ensures that the appropriate state or tribal personnel are contacted in order to effect the appropriate involvement of state or tribal officials and resources. If the emergency is such that personnel or equipment are needed at the accident scene, the RCO coordinates the activation of a DOE Radiological Assistance Program (RAP) team. The RCO offices and phone numbers are listed in Attachment A.

\subsection{EMERGENCY RESPONSE}

The emergency-related roles and responsibilities that support this Shipment Plan are outlined below. As the DOE-designated shipper, INEEL will provide shipper-related emergency information and maintain a 24-hour emergency telephone contact [phone (208) 526-1515] for technical advice and detailed information regarding the shipments.

- The carrier driver, if able, will make the emergency notifications previously described and will undertake first-aid actions, control the initial accident scene, provide assistance to first responders, and perform other emergency actions as described in the carrier's emergency response plan.

- First responders (local law enforcement, fire fighters, and emergency medical service personnel) will be guided in their initial response actions by information contained in the 1996 North American Emergency Response Guidebook. Guide 165 (Ref. 10) applies to the shipment of the irradiated capsules and is attached for reference (Attachment D). The Guidebook shall be in possession of the driver, and Guide 165 or other similar information must be attached to the shipping papers.

- The carrier will be given first opportunity to dispatch a crew to the affected area. The states maintain specialized state-level hazardous materials or radiological assistance teams (RATs) that may be activated to provide technical assistance and mitigation during emergencies. DOE will provide RATs from one of its regional offices to advise or assist in cleanup operations, if requested.

- $\quad$ All public contact and release of information will be coordinated through the local officials who have established an incident command. All information released will be with the concurrence of all parties involved with the transportation and local incident command. 


\subsection{RECOVERY}

The carrier has primary responsibility for package and tractor-trailer recovery operations. Recovery will not begin until the emergency phase of any accident is terminated, following a decision that no further radiological or other hazard is present. DOE will assist the carrier in recovery operations, where appropriate. States can exercise their vehicle inspection responsibilities before permitting the recovered vehicle to proceed to its destination, the nearest DOE facility, or to return to the shipper.

\subsection{CLEANUP AND SITE RESTORATION}

The carrier has primary responsibility for cleanup and site restoration following an emergency. Standards for such actions will be as established by regulation and by authorities in the affected jurisdictions.

After the immediate threat of the accident has passed, the lead federal radiological monitoring and assessment role is transferred from DOE to the U.S. Environmental Protection Agency (EPA). Although DOE would recover the irradiated test fuel (should that be necessary), it is the responsibility of the shipper to repackage and dispose of, as appropriate, any primary radioactive material spilled, plus any contaminated material.

\section{PHYSICAL PROTECTION}

The shipper, INEEL, acting on behalf of DOE, is required by DOE to meet the NRC physical protection requirements. Based on the quantities of materials involved in each planned shipment, some of the shipments (particularly the $3^{\text {rd }}$ shipment of either the APT or HPT) may meet the quantity limits for "special nuclear material, of low strategic-significance" when offering the material to a carrier. The defining limit for materials of "low strategic significance" is special nuclear material containing more than $15 \mathrm{~g}$ of plutonium, but less than $500 \mathrm{~g}$. DOE is exempt from the NRC requirements when using a DOE transport system [10 CFR Part 73.6 (d)]; however, since a commercial carrier will be involved, and the DOE requirements for physical protection of nuclear materials in transit are found in the NRC regulations [per DOE Orders 460.1A (Ref. 11) and 460.2 (Ref. 12)]. The planned shipments of the irradiated MOX capsules meet the requirements for low strategic-significance material.

The in-transit regulations for low strategic-significance material are found in 10 CFR Part 73.67 (g)(4). The regulations require a response plan or procedures to deal with either threat or theft. INEEL shall comply accordingly.

\section{INSURANCE AND LIABILITY ISSUES}

The carrier will maintain necessary insurance and liability coverage for the shipments. The shipper will verify the carrier's insurance and liability coverage. 


\section{REFERENCES}

1. B.S. Cowell and S.A. Hodge, Fissile Materials Disposition Program Light Water Reactor Mixed Oxide Fuel Irradiation Test Project Plan, Revision 1, ORNL/MD/LTR-78, Lockheed Martin Energy Research Corp., Oak Ridge National Laboratory, Oak Ridge, Tennessee, February 1998 (revision to July 1997 plan).

2. B. S. Cowell, ATR Capsule Assembly Loading and Operation Schedule, ORNL/MD/LTR91, Revision 1, Lockheed Martin Energy Research Corp., Oak Ridge National Laboratory, Oak Ridge, Tennessee, February 1998 (revision to September 1997 plan).

3. L. S. Dickerson and M. J. Welch, Fresh Test Fuel Shipment Plan for the LWR MOX Fuel Irradiation Test Project, ORNL/MD/LTR-87, Rev. 0, Lockheed Martin Energy Research Corp., Oak Ridge National Laboratory, Oak Ridge, Tennessee, September 12, 1997.

4. B.S. Cowell and S.A. Hodge, Fissile Materials Disposition Program Light Water Reactor Mixed Oxide Fuel Irradiation High Power Test Project Plan, ORNL/MD/LTR-125, Revision 1, Lockheed Martin Energy Research Corp., Oak Ridge National Laboratory, Oak Ridge, Tennessee, July 1998 (revision to April 1998 plan).

5. B. S. Cowell, ATR Capsule Assembly Loading and Operation Schedule for the High-Power Mixed-Oxide Irradiation Test, ORNL/MD/LTR-132, Revision 1, Lockheed Martin Energy Research Corp., Oak Ridge National Laboratory, Oak Ridge, Tennessee, July 1998 (revision to June 1998 plan).

6. U.S. Department of Energy, "Motor Carrier Evaluation Program (MCEP)," from the Environmental Management Home Page, http://www.em.doe.gov/trans/mcep.html, Sept. 15, 1995.

7. Federal Highway Administration, U.S. Department of Transportation, Federal Motor Carrier Safety Regulations, Chapter III, Subpart B, Appendix G, Minimum Periodic Inspection Standards.

8. Commercial Vehicle Safety Alliance, "North American Uniform Out-of-Service Criteria," Appendix A, Parts I, II, and III, April 1, 1995.

9. B. S. Cowell, Technical Specifications: Mixed-Oxide Pellets for the Light-Water Reactor Irradiation Demonstration Test, ORNL/MD/LTR-75, Lockheed Martin Energy Research Corp., Oak Ridge National Laboratory, Oak Ridge, Tennessee, June 1997.

10. Research and Special Programs Administration, U. S. Department of Transportation, 1996 North American Emergency Response Guidebook, Washington, D.C., 1996.

11. U.S. Department of Energy, "Packaging and Transportation Safety," DOE Order 460.1A, Washington, D.C., Oct. 2, 1996.

12. U. S. Department of Energy, "Departmental Material Transportation and Packaging Management," DOE Order 460.2, Change 1, Washington, D.C., October 26, 1996. 
ATTACHMENT A

TELEPHONE NUMBERS OF DOE REGIONAL COORDINATING OFFICES 
Page Intentionally Blank 
1. Region 1: Brookhaven

516-282-2200

2. Region 2: Oak Ridge 423-576-1005

3. Region 3: Savannah River

803-725-3333

4. Region 4: Albuquerque 505-845-4667

5. Region 5: Chicago

708-252-4000

6. Region 6: Idaho

208-526-1515

7. Region 7: Oakland

510-637-1821

8. Region 8: Richland

509-373-3800 
Page Intentionally Blank 
ATTACHMENT B

MATERIAL ISOTOPIC ANALYSIS 
Page Intentionally Blank 


\section{MATERIAL ISOTOPIC ANALYSIS}

The LWR MOX fuel irradiation tests involve the irradiation of MOX fuel test specimen capsules in the ATR at INEEL. In the first test (known as the Average Power Test), 11 capsules will undergo burnups from 8 to $30 \mathrm{GWd} / \mathrm{MT}$. Beginning in early 1999, a second test (known as the High Power Test) will subject a total of 13 capsules to burnups ranging from 15 to $45 \mathrm{GWd} / \mathrm{MT}$.

Unlike the fresh MOX fuel capsules, the irradiated capsules will need to be shipped in a shielded cask to reduce the external package dose rate to safe levels during handling and transport. Using the ORIGEN-S code, the characteristics of the discharged MOX fuel test specimen capsules were evaluated as a function of burnup and decay time after reactor shutdown. This information provides a foundation for (a) identifying the radiation source terms for the capsules as a function of time after discharge, (b) determining the proper shielding required to protect workers during handling operations, and (c) evaluating the various packagings that may be used to transport the capsules from INEEL to ORNL.

Table B.1 presents information on the approximate curie levels expected in each irradiated capsule as a function of burnup and time after shutdown of the reactor. The individual isotopes are consolidated into three major groups of light elements, actinides, and fission products. Note that for a given cooling time, activity levels from the light elements and actinides increase almost in direct proportion to the burnup. The activity levels from fission products, however, vary only a little with burnup, and in fact, decrease slightly at the higher burnup level. This is primarily due to the fact that in order to achieve the higher burnups (e.g., 20 and $30 \mathrm{GWd} / \mathrm{MT}$ ) the capsules are irradiated through a number of reactor operating cycles, between which the reactor is shut down to, for example, remove experiments. Many of the shorter-lived fission products generated in early irradiation cycles have decayed by the time the higher burnups are reached.

As the burnup increases, the fissionable isotopes $\left({ }^{235} \mathrm{U},{ }^{239} \mathrm{Pu}\right.$, and $\left.{ }^{241} \mathrm{Pu}\right)$ decrease. This is shown in Table B.2. After a burnup of $8 \mathrm{GWd} / \mathrm{MT}$ has been achieved, there remains a total of about 3.12 grams of fissile material in each capsule. After 20 and $30 \mathrm{GWd} / \mathrm{MT}$, the total fissile material in each capsule has decreased to approximately 1.77 and 1.09 grams, respectively. The fissionable plutonium isotopes follow this same pattern, decreasing from 2.95 grams after a burnup of $8 \mathrm{GWd} / \mathrm{MT}$ to 1.03 grams after $30 \mathrm{GWd} / \mathrm{MT}$.

Note: Table B.1 and B.2 provide estimates of the radioactivity and composition of the irradiated MOX fuel test specimen capsules for the Average-Power Test. As part of preparing each shipment for transport, INEEL will be responsible for providing more precise and detailed information about the isotopic composition of each shipment on the official shipping papers and as part of any safety analysis that may be required by INEEL or DOE procedures. 
Table B.1 Irradiated Fuel Capsule Activity - Average Power Test

\begin{tabular}{|c|l|c|c|c|}
\hline \multirow{2}{*}{$\begin{array}{c}\text { Average Burnup } \\
\text { GWd/MT }\end{array}$} & & \multicolumn{3}{|c|}{ Curies } \\
\cline { 3 - 5 } & & 30 days decay & 60 days decay & 90 days decay \\
\hline \multirow{2}{*}{8} & Light elements & $1.07 \mathrm{E}+01$ & $1.09 \mathrm{E}+01$ & $6.95 \mathrm{E}+00$ \\
& Actinides & $7.17 \mathrm{E}+00$ & $6.71 \mathrm{E}+00$ & $6.43 \mathrm{E}+00$ \\
& Fission products & $9.53 \mathrm{E}+02$ & $6.11 \mathrm{E}+02$ & $4.37 \mathrm{E}+02$ \\
& Total & $9.71 \mathrm{E}+02$ & $6.29 \mathrm{E}+02$ & $4.50 \mathrm{E}+02$ \\
\hline 20 & Light elements & $2.97 \mathrm{E}+01$ & $1.97 \mathrm{E}+01$ & $1.47 \mathrm{E}+01$ \\
& Actinides & $1.37 \mathrm{E}+01$ & $1.34 \mathrm{E}+01$ & $1.33 \mathrm{E}+01$ \\
& Fission products & $9.45 \mathrm{E}+02$ & $6.59 \mathrm{E}+02$ & $5.08 \mathrm{E}+02$ \\
& Total & $9.89 \mathrm{E}+02$ & $6.92 \mathrm{E}+02$ & $5.36 \mathrm{E}+02$ \\
\hline 30 & Light elements & $4.00 \mathrm{E}+01$ & $2.86 \mathrm{E}+01$ & $2.29 \mathrm{E}+01$ \\
& Actinides & $2.12 \mathrm{E}+01$ & $2.06 \mathrm{E}+01$ & $2.02 \mathrm{E}+01$ \\
& Fission products & $7.89 \mathrm{E}+02$ & $5.74 \mathrm{E}+02$ & $4.59 \mathrm{E}+02$ \\
& Total & $8.50 \mathrm{E}+02$ & $6.23 \mathrm{E}+02$ & $5.02 \mathrm{E}+02$ \\
\hline
\end{tabular}

Note: "Light elements" are also known as "activation products". Calculated composition based on one MOX capsule.

Table B.2 Irradiated Fuel Capsule Actinide Composition - Average Power Test

\begin{tabular}{|c|c|c|c|}
\hline \multirow{2}{*}{ Isotope } & \multicolumn{3}{|c|}{ Amount in one fuel capsule (g) } \\
\cline { 2 - 4 } & 8 GWd/MT & 20 GWd/MT & 30 GWd/MT \\
\hline${ }^{235} \mathrm{U}$ & $1.70 \mathrm{E}-01$ & $8.63 \mathrm{E}-02$ & $5.80 \mathrm{E}-02$ \\
\hline${ }^{236} \mathrm{U}$ & $4.87 \mathrm{E}-03$ & $8.40 \mathrm{E}-03$ & $1.27 \mathrm{E}-02$ \\
\hline${ }^{238} \mathrm{U}$ & $7.18 \mathrm{E}+01$ & $7.09 \mathrm{E}+01$ & $7.07 \mathrm{E}+01$ \\
\hline${ }^{239} \mathrm{Pu}$ & $2.91 \mathrm{E}+00$ & $1.56 \mathrm{E}+00$ & $8.65 \mathrm{E}-01$ \\
\hline${ }^{240} \mathrm{Pu}$ & $4.67 \mathrm{E}-01$ & $7.14 \mathrm{E}-01$ & $7.93 \mathrm{E}-01$ \\
\hline${ }^{241} \mathrm{Pu}$ & $4.04 \mathrm{E}-02$ & $1.19 \mathrm{E}-01$ & $1.70 \mathrm{E}-01$ \\
\hline${ }^{242} \mathrm{Pu}$ & $3.02 \mathrm{E}-03$ & $2.32 \mathrm{E}-02$ & $5.75 \mathrm{E}-02$ \\
\hline
\end{tabular}

Note: Calculated composition based on one MOX capsule. 
ATT ACHMENT C

ROUTING ANALYSIS FOR LWR MOX IRRADIATED FUEL IRRADIATION TESTINEEL TO ORNL 
Page Intentionally Blank 


\section{ROUTING ANALYSIS FOR LWR MOX IRRADIATED FUEL IRRADIATION TEST- INEEL to ORNL}

\section{C.1 PURPOSE OF THE SHIPMENTS}

The purpose of the planned shipments is to transport irradiated MOX fuel test specimen capsules from INEEL to ORNL so that the capsules may undergo PIE. A total of two shipping campaigns are planned, with a maximum of three shipments per campaign. The first shipping campaign involves capsules irradiated during the Average Power Test, which commenced irradiation in February 1998. Under this campaign, the first shipment will include two irradiated capsules and should commence shortly after these two capsules have been discharged from the ATR reactor (scheduled for September 1998). Two other shipments (of two capsules and seven capsules) will follow at intervals of approximately 12 months after the first shipment. A second shipping campaign, for capsules irradiated under the High Power Test, is planned. As before, a total of three shipments would occur at approximately 12 month intervals. It may be possible to ship APT and HPT irradiated capsules in a single shipment, thus reducing both the number of shipments and project costs.

Two routes have been calculated using the software program called HIGHWAY, which has been developed by DOE specifically to select routes for shipments of radioactive materials using criteria set forth in DOT regulations. Two possible routes are detailed below. Both routes may be considered as preferred routes. However, the actual shipment route will be specified in the final arrangements among INEEL, the carrier, and ORNL.

\section{2 SHIPMENT DESCRIPTION}

The shipment will be conducted using a commercial carrier and will use a certified packaging in which the irradiated capsules will be placed. Each irradiated capsule is composed of a stainless steel tube and end caps that are seal-welded to encapsulate a sealed, zircaloy clad MOX fuel pin. Some shipments may have as few as a single irradiated capsules while other shipments could have as many as 8 capsules.

\section{3 ROUTING ANALYSIS}

A preliminary isotopic analysis of APT irradiated capsules is given in Appendix B. Clearly, each irradiated capsule will contain sufficient activity to require the use of a Type $B$ package. A Type $B$ package is required when the radioactive contents exceed either the $A_{1}$ or $A_{2}$ limits set forth in the DOT regulations. Any shipment of radioactive material within a single package that exceeds 3000 times either the $A_{1}$ or $A_{2}$ value is by definition a highway route controlled quantity (HRCQ) shipment. Additionally, when isotopic mixtures are involved, all isotopes must be evaluated relative to their unique $A_{1}$ or $A_{2}$ values to determine if the mixture exceeds a HRCQ. HRCQ shipments must follow the regulations for the routing for radioactive materials, which are found in 49 CFR Part 397.101. INEEL will need to determine if any of the planned shipments will be 
designated as HRCQ and take the necessary steps to ensure that these shipments comply with the additional labels and placarding requirements.

Using the HIGHWAY code, two possible routes were selected. Because of the uncertainty about the actual radioactive composition of each shipment, the HM-164/state-preferred routing criteria were employed. Thus, the routes evaluated are HRCQ routes. Basically, the routing criteria dictate that (1) the shipment maximizes use the U.S. Interstate Highway system, (2) the shipment uses the shortest distance route from the origin to the Interstate and from the Interstate to the destination, (3) shipment time is minimized, (4) the shipment uses state-designated "preferred" routes and Interstate bypasses around cities.

A. The preferred route (Route A) is 27 miles longer than the Route B, but takes about one half hour less driving. Route A goes south on I-15 to Utah joining I-84, and then turns southeasterly and connects with I-80 to proceed east from Utah through Wyoming and Nebraska (with a deviation around Omaha) to I-29. It then follows I-29 south through southwestern Iowa and northwestern Missouri, circumventing the Kansas City area to access I-70 and follows it to St. Louis, Missouri. Circumventing the city of St. Louis, it proceeds southeastward to Mt. Vernon, Illinois, and then south via I-57 to I-24 at Pulleys Mill, Illinois. The route then follows I-24 through Paducah, Kentucky, to Nashville, Tennessee, and then proceeds eastward to Oak Ridge, Tennessee, by I-40 and State 95.

B. The alternative preferred route, although shorter than Route A, takes additional driving time due to slower driving times around Denver and lower speed limits in Kansas. Route B follows the same path from INEEL to Laramie, Wyoming, where it proceeds south on I-25 to Denver, Colorado. At Denver, it forks easterly onto I-76 and then I-270 before joining I70 and proceeds through eastern Colorado and Kansas. Near Kansas City, Kansas, it follows I-435 around the southern part of the metropolitan area. Southeast of Kansas City, Missouri, it rejoins the preferred route and follows the same path to ORNL.

Table C.1 provides a brief summary of potential transportation routes between INEEL and ORNL. Figure C.1 provides a map of the two representative routes.

Tables C. 2 through C. 3 contain the detailed HIGHWAY output for each of the two representative routes between INEEL and ORNL. Each HIGHWAY output has three general segments of information. The first provides a brief description and summary of the route, including summaries of the route by type of road. The second segment of the HIGHWAY output (Routing through) provides a detailed listing of the calculated route. Finally, the third segment provides a detailed listing of the population density and a summary that provides input to RADTRAN, DOE's tool for calculating transportation risk assessment. 
Table C.1 Summary—Selected transportation routes between INEEL

\begin{tabular}{|l|c|c|c|c|c|}
\hline \multicolumn{1}{|c|}{ Route identification } & $\begin{array}{c}\text { Distance } \\
\text { (miles) }\end{array}$ & $\begin{array}{c}\text { Time } \\
\text { (h) }\end{array}$ & \multicolumn{3}{c|}{$\begin{array}{c}\text { Population density } \\
\text { (population/mile }\end{array}$} \\
\hline & & & Rural & Suburban & Urban \\
\hline Route A, preferred route & 2079 & $33: 58$ & 16.5 & 846.6 & 5705.1 \\
\hline Route B, alternative preferred & 2052 & $34: 27$ & 16.5 & 865.6 & 5588.6 \\
\hline
\end{tabular}

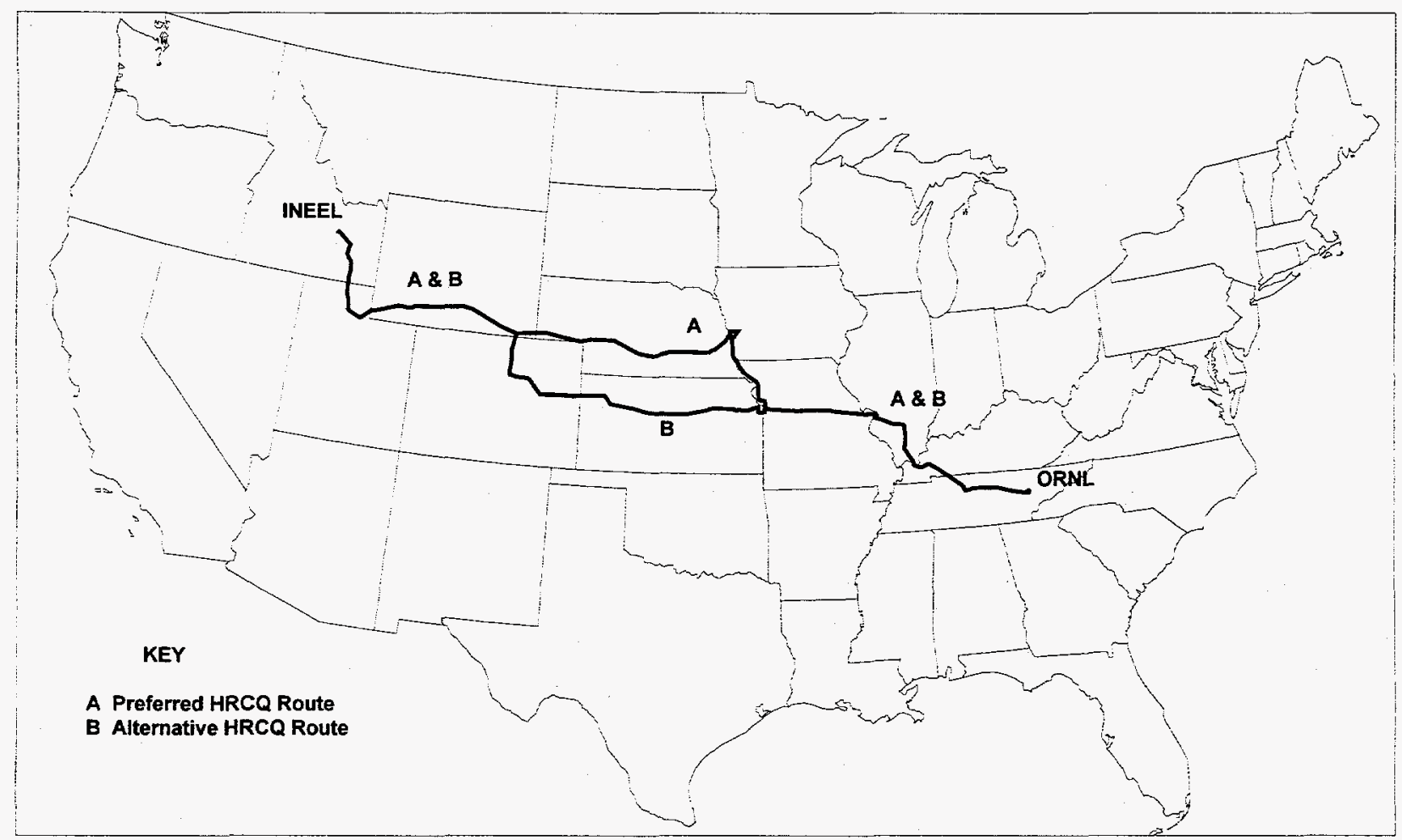

Figure C.1 Map of representative routes between INEEL and ORNL. 
Table C.2 Route A between INEEL and ORNL

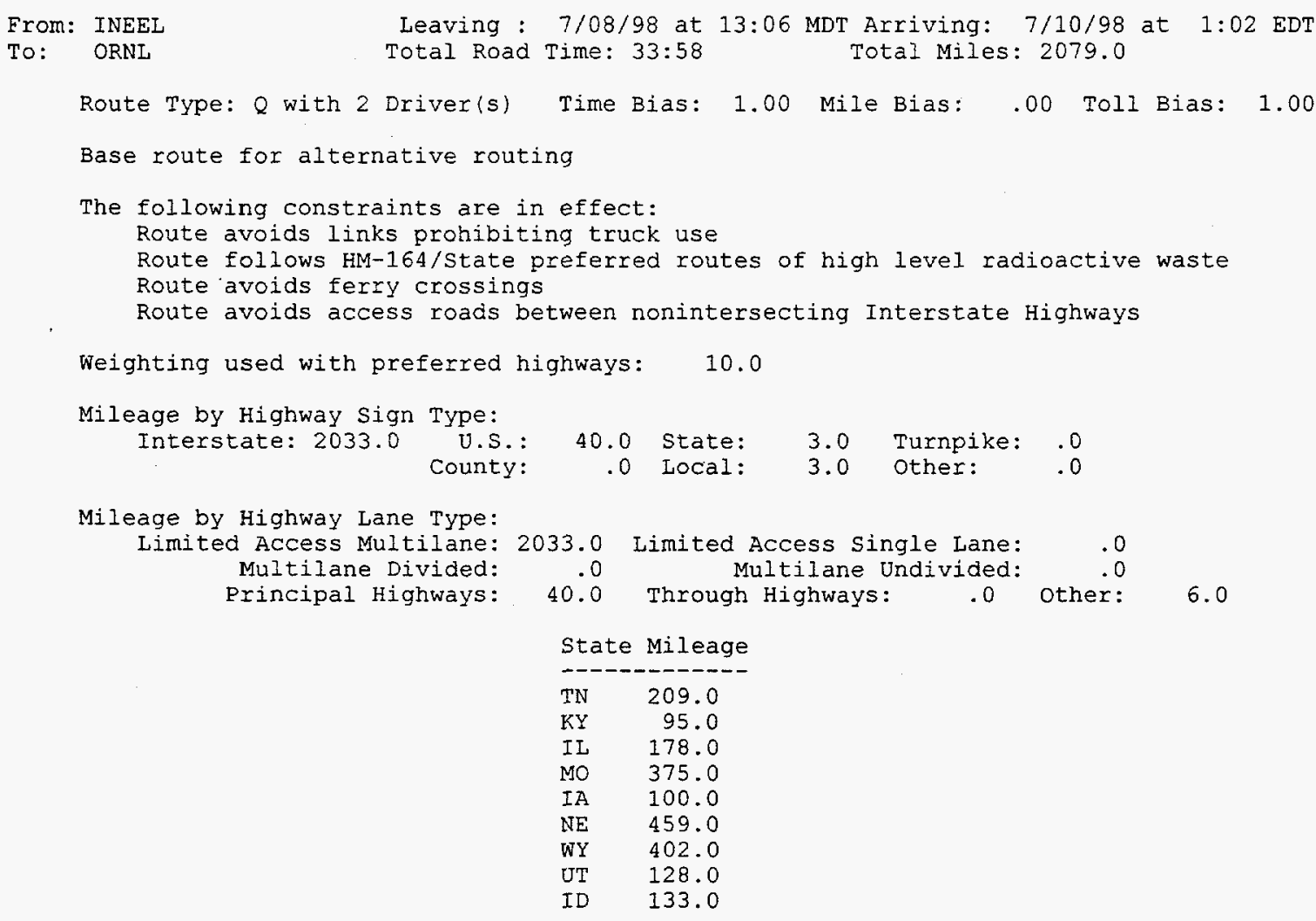

From: INEEL

TO: ORNL

Leaving : 7/08/98 at 13:06 MDT Arriving: 7/10/98 at 1:02 EDT Total Road Time: 33:58

Total Miles: 2079.0

Route Type: Q with 2 Driver(s) Time Bias: 1.00 Mile Bias: .00 Toll Bias: 1.00

Base route for alternative routing

The following constraints are in effect:

Route avoids links prohibiting truck use

Route follows HM-164/State preferred routes of high level radioactive waste

Route avoids ferry crossings

Route avoids access roads between nonintersecting Interstate Highways

Weighting used with preferred highways: 10.0

Mileage by Highway Sign Type:

Interstate: 2033.0 U.S.: 40.0 State: $\quad \begin{array}{rlr}3.0 & \text { Turnpike: } .0\end{array}$

County: $\quad .0$ Locil: 3.0 other: .0

Mileage by Highway Lane Type:

Limited Access Multilane:

Multilane Divided:

2033.0

Principal Highways:

\begin{tabular}{cc} 
40.0 & Through \\
State & Mileage \\
\hline TN & 209.0 \\
KY & 95.0 \\
IL & 178.0 \\
MO & 375.0 \\
IA & 100.0 \\
NE & 459.0 \\
WY & 402.0 \\
UT & 128.0 \\
ID & 133.0
\end{tabular}

Access Single Lane:

.0

tilane Undivided:

.0 other: 6.0

Routing through:

\begin{tabular}{|c|c|c|c|c|c|c|c|}
\hline .0 & & & INEEL & & & & \\
\hline 1.0 & LOCAI & & ID NATL ENG LAB & & 020 & LOCI & \\
\hline 4.0 & $\mathbf{u} 20$ & U26 & ATOMIC CITY & NW & $\mathrm{U} 20$ & $\mathrm{U} 26$ & \\
\hline 36.0 & $\mathrm{U} 26$ & & BLACKEOOT & NW & I 15 & $x 92$ & \\
\hline 112.0 & I 15 & & TREMONTON & $w$ & I 15 & 184 & \\
\hline 39.0 & I 15 & I 84 & OGDEN & $S$ & I 15 & I 84 & \\
\hline & I 84 & & $\mathrm{ECHO}$ & & 180 & I84 & \\
\hline 877.0 & I 80 & & OMAHA & SW & I 680 & 180 & \\
\hline 17.0 & 1680 & & CRESCENT & $w$ & I 29 & I 680 & \\
\hline 10.0 & I29 & I 680 & LOVELAND & SW & 129 & I 680 & \\
\hline 16.0 & I 680 & & MINDEN & NW & I 680 & I 80 & \\
\hline 23.0 & 180 & & COUNCII BLUEES & $S E$ & 129 & 180 & \\
\hline 157.0 & 129 & & KANSAS CITY & NW & I 29 & \pm 435 & \\
\hline 28.0 & I 435 & & KANSAS CITY & $S E$ & I 435 & 170 & \\
\hline 224.0 & I70 & & ST LOUIS & NW & 1270 & 170 & \\
\hline 22.0 & I 270 & & EDWARDSVILLE & SW & $I 255$ & $I 270$ & \\
\hline 11.0 & I 255 & & WASHINGTON PK & $S E$ & $I 255$ & I 64 & \\
\hline 67.0 & I 64 & & MT VERNON & NW & I57 & I 64 & \\
\hline 5.0 & 157 & I64 & MT VERNON & SW & 157 & I 64 & \\
\hline 48.0 & 157 & & PULLEYS MILL & $W$ & I24 & I57 & \\
\hline 179.0 & 124 & & INGIEWOOD & $w$ & $I 24$ & I65 & \\
\hline 5.0 & I24 & I 65 & NASHVILLE & $S E$ & I24 & 140 & \\
\hline 2.0 & I 24 & I 40 & NASHVILLE & $E$ & I24 & $I 40$ & \\
\hline 52.0 & I 40 & & IENOIR CITY & NW & $I 40$ & $\times 364$ & \\
\hline 3.0 & S95 & & $x-10$ & W & S95 & LOCL & \\
\hline 2 & LOCAL & & ORNL & & & & \\
\hline
\end{tabular}

$\begin{array}{rrr}.0 & 0: 00 & 7 / 08 / 98 \text { at } 13: 06 \\ 1.0 & 0: 02 & 7 / 08 / 98 \text { at } 13: 08 \\ 5.0 & 0: 07 & 7 / 08 / 98 \text { at } 13: 13 \\ 41.0 & 0: 50 & 7 / 08 / 98 \text { at } 13: 56 \\ 153.0 & 2: 20 & 7 / 08 / 98 \text { at } 15: 25 \\ 192.0 & 2: 56 & 7 / 08 / 98 \text { at } 16: 01 \\ 231.0 & 3: 27 & 7 / 08 / 98 \text { at } 16: 32 \\ 1108.0 & 16: 40 & 7 / 09 / 98 \text { at } 6: 46 \\ 1125.0 & 16: 59 & 7 / 09 / 98 \text { at } 7: 04 \\ 1135.0 & 17: 08 & 7 / 09 / 98 \text { at } 7: 13 \\ 1151.0 & 17: 23 & 7 / 09 / 98 \text { at } 7: 28 \\ 1174.0 & 18: 14 & 7 / 09 / 98 \text { at } 8: 19 \\ 1331.0 & 20: 33 & 7 / 09 / 98 \text { at } 10: 38 \\ 1359.0 & 20: 57 & 7 / 09 / 98 \text { at } 11: 02 \\ 1583.0 & 24: 41 & 7 / 09 / 98 \text { at } 14: 46 \\ 1605.0 & 25: 04 & 7 / 09 / 98 \text { at } 15: 09 \\ 1616.0 & 25: 16 & 7 / 09 / 98 \text { at } 15: 21 \\ 1683.0 & 26: 29 & 7 / 09 / 98 \text { at } 16: 34 \\ 1688.0 & 27: 04 & 7 / 09 / 98 \text { at } 17: 09 \\ 1736.0 & 27: 57 & 7 / 09 / 98 \text { at } 18: 01 \\ 1915.0 & 30: 49 & 7 / 09 / 98 \text { at } 20: 54 \\ 1920.0 & 30: 55 & 7 / 09 / 98 \text { at } 20: 59 \\ 1922.0 & 30: 57 & 7 / 09 / 98 \text { at } 21: 02 \\ 2074.0 & 33: 49 & 7 / 10 / 98 \text { at } 0: 54 \\ 2077.0 & 33: 55 & 7 / 10 / 98 \text { at } 1: 00 \\ 2079.0 & 33: 58 & 7 / 10 / 98 \text { at } 1: 02\end{array}$


Population Density from: INEEL

TO ORNL

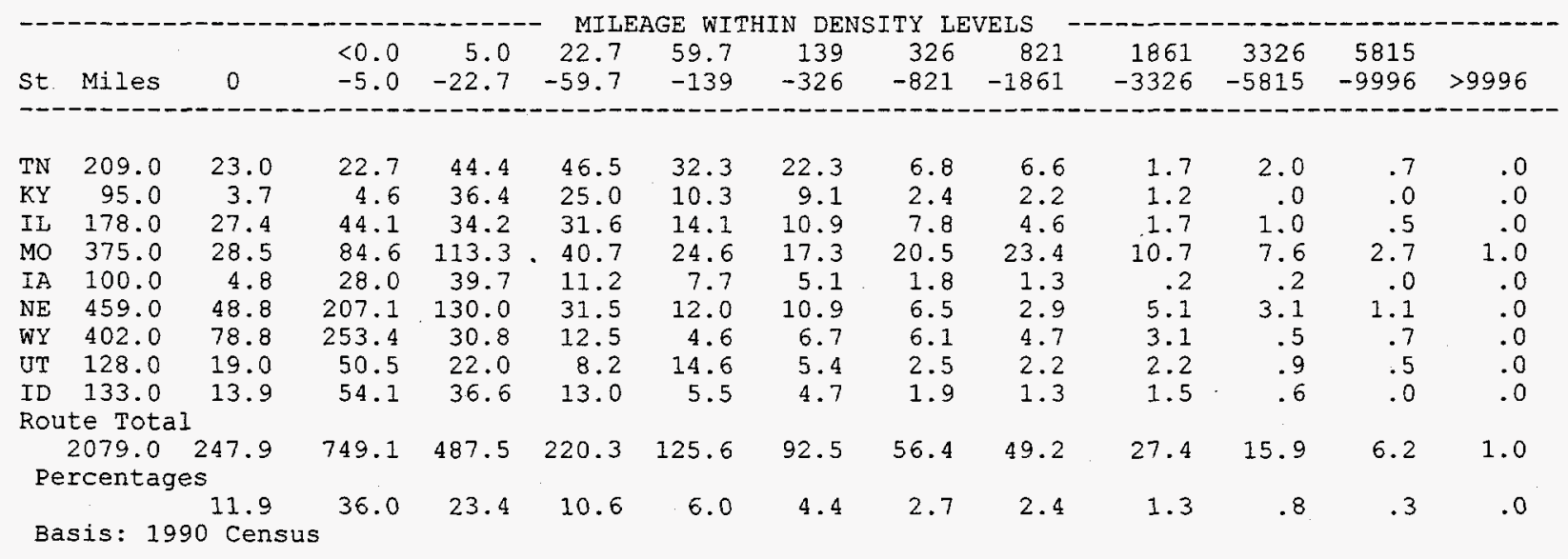

$\begin{array}{lrrrr}\text { RADTRAN Input Data } & \text { Rural suburban } & \text { Urban } \\ \text { Weighted Population } & & & & \\ \text { People/sq. mi. } & 16.5 & 846.6 & 5705.1 & \\ \text { People/sq. km. } & 6.4 & 326.9 & 2202.7 & \text { Total } \\ & & & & 2079.0 \\ \text { Distance } & 1830.4 & 225.5 & 23.1 & 3345.7 \\ \text { Miles } & 2945.6 & 362.9 & 37.1 & \\ \text { Kilometers } & 88.0 & 10.8 & 1.1 & \\ \text { Percentage } & <139 & 139-3326 & >3326 & 1990 \text { Census } \\ \text { Basis (people/sq. mi.) } & <1326 \\ \text { Note: Due to rounding, the sum of the mileages in the individual } \\ \text { population categories may not equal the total mileage shown } \\ \text { on this report. }\end{array}$


Table C.3 Route B between INEEL and ORNL

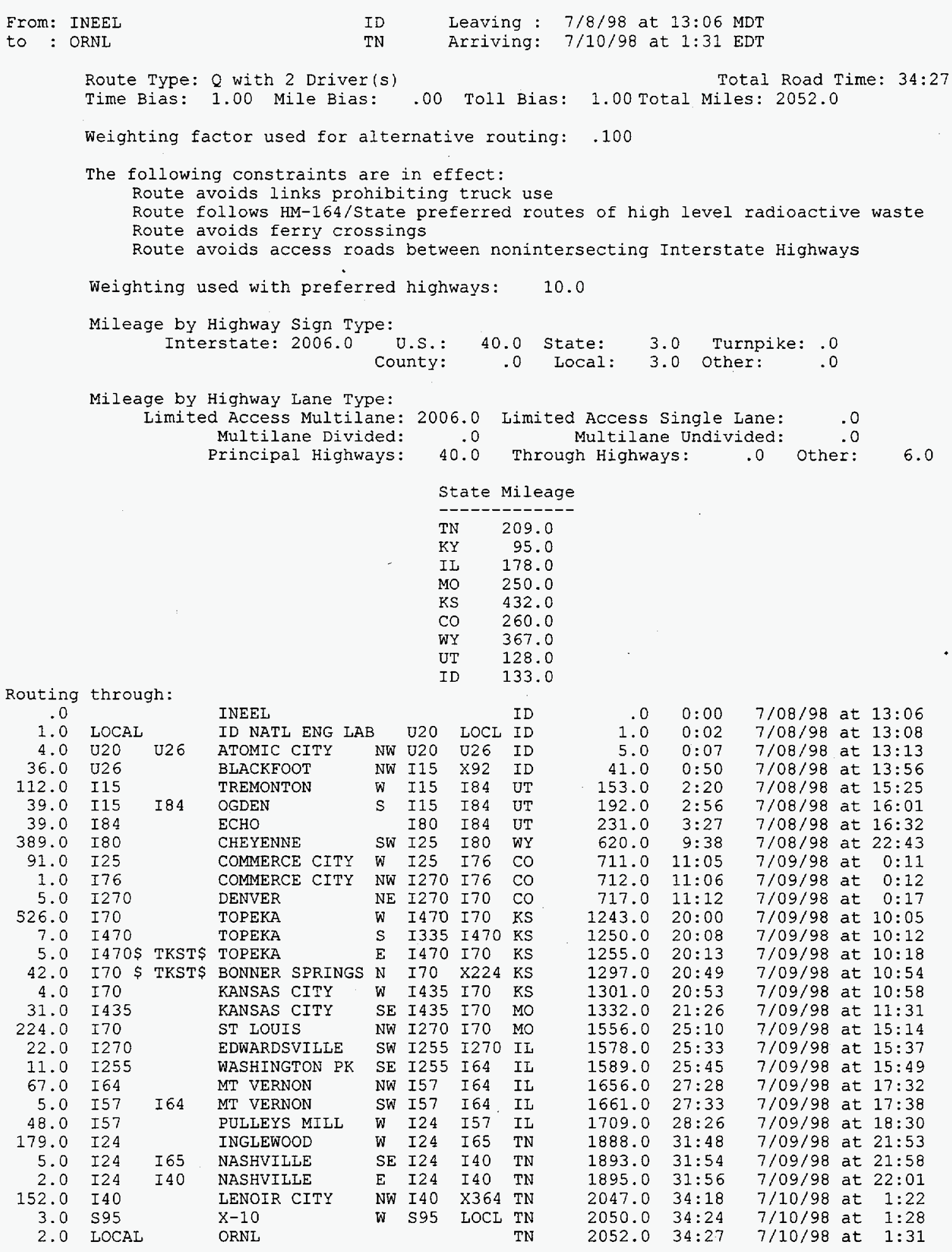


Table C.3 Route B between INEEL and ORNL (continued)

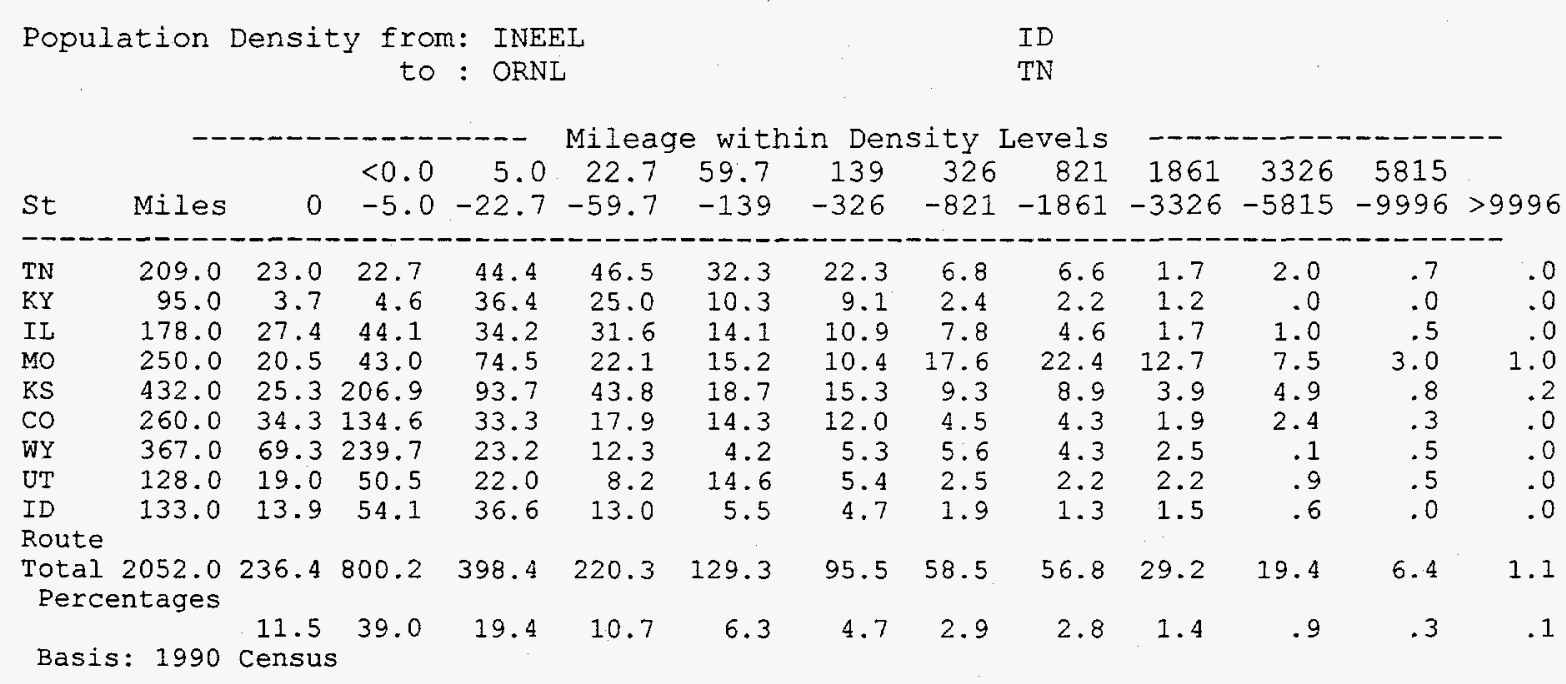

$\begin{array}{lrrrr}\text { RADTRAN Input Data } & \text { Rural } & \text { Suburban } & \text { Urban } \\ \text { Weighted Population } & & & \\ \text { People/sq. mi. } & 16.5 & 865.6 & 5588.6 & \\ \text { People/sq. km. } & 6.4 & 334.2 & 2157.8 & \\ \text { Distance } & & & & \text { Total } \\ \text { Miles } & 1784.6 & 240.1 & 26.9 & 2052.0 \\ \text { Kilometers } & 2871.9 & 386.4 & 43.3 & 3302.3 \\ \text { Percentage } & 87.0 & 11.7 & 1.3 & \\ \text { Basis (people/sq. mi.) } & <139 \text { 139-3326 } & >3326 & 1990 \text { Census } \\ & \\ \text { Note: Due to rounding, the sum of the mileages in the individual } \\ \text { population categories may not equal the total mileage shown } \\ \text { on this report. }\end{array}$


Page Intentionally Blank 


\section{ATTACHMENT D}

GUIDE 165, RADIOACTIVE MATERIALS (FISSILE-LOW TO HIGH LEVEL RADIATION) FROM THE 1996 NORTH AMERICAN EMERGENCY RESPONSE GUIDE 
Page Intentionally Blank 


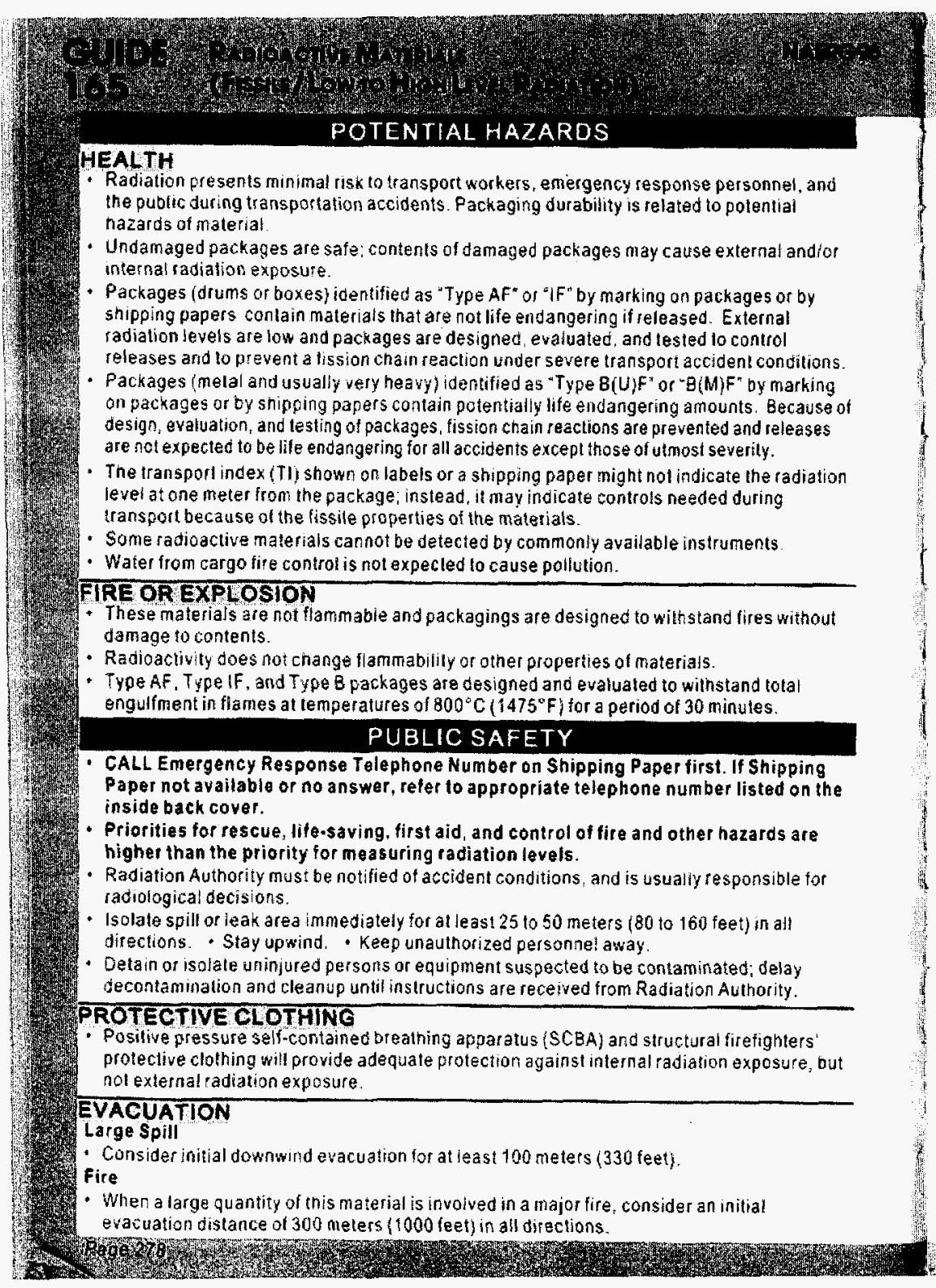

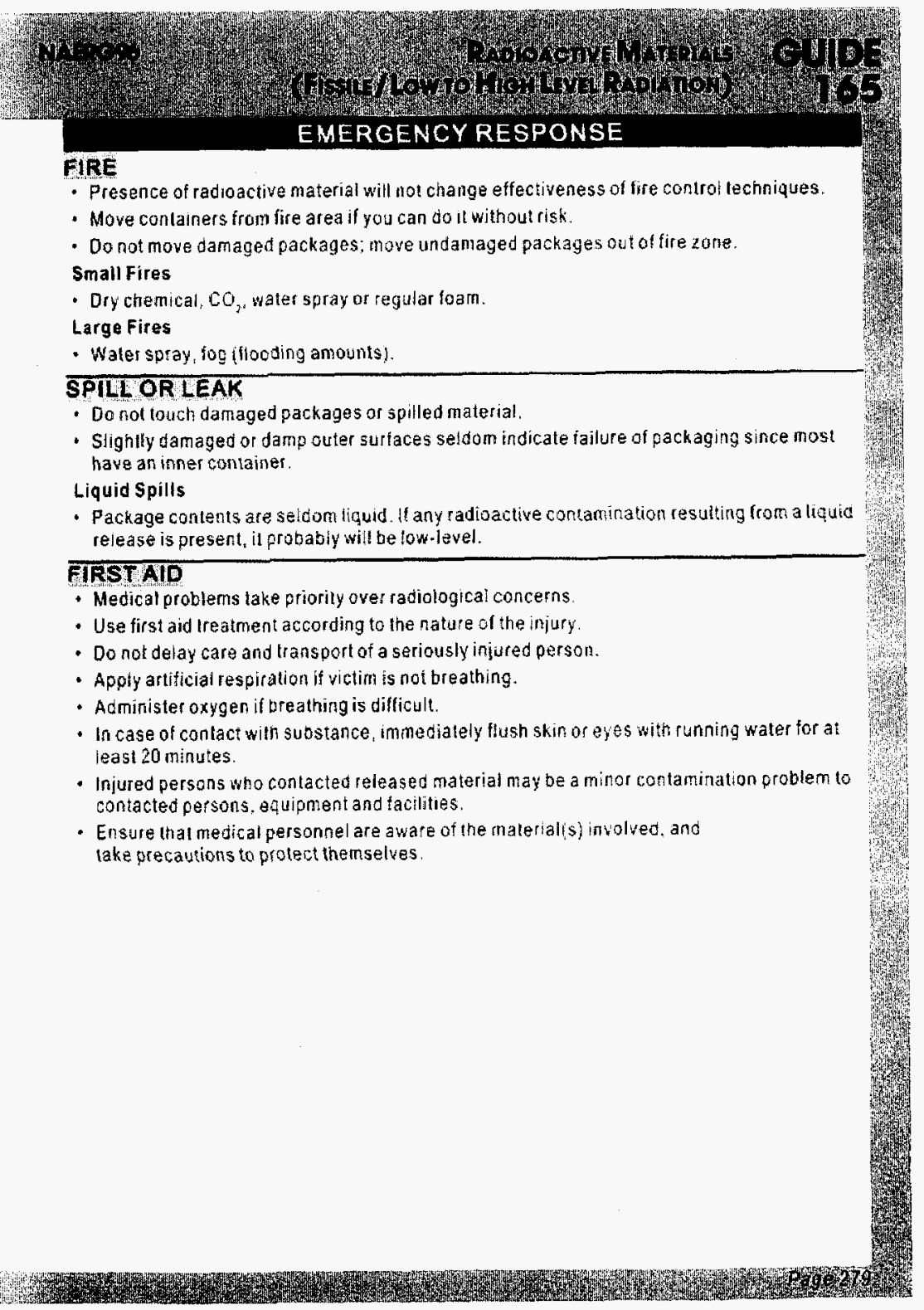




\section{INTERNAL DISTRIBUTION}

1. B. S. Cowell

2. C. E. DeVore

3. L. S. Dickerson

4. C. E. Eblen

5. S. E. Fisher

6. S. R. Greene

7. D. W. Heatherly

8. S. A. Hodge

9. S. B. Ludwig

10. S. D. McGhee

11. W. A. Miller

12. R. N. Morris
13. L. J. Ott

14. R. B. Pope

15. R. T. Primm

16. P. L. Rittenhouse

17. L. B. Shappert

18. K. R. Thoms

19. Central Research Library

20-21. ORNL Laboratory Records(OSTI)

22. ORNL Laboratory Records-RC

\section{EXTERNAL DISTRIBUTION}

23. D. Alberstein, Los Alamos National Laboratory, P.O. Box 1663, MS-K575, Los Alamos, NM 87545.

24-25. K. Chidester, Los Alamos National Laboratory, P.O. Box 1663, MS-E502, Los Alamos, NM 87545.

26. H. E. Clark, U.S. Department of Energy, Oak Ridge Operations, P.O. Box 2008, Oak Ridge, TN 37831-6269.

27. S. L. Eaton, Los Alamos National Laboratory, P.O. Box 1663, TSA-10, MS K551, Los Alamos, NM 87545.

28. P. M. Kasik, MPR Associates Inc., 320 King Street, Alexandria, VA 22314-3238.

29. P. B. Lester, U.S. Department of Energy, Oak Ridge Operations, P.O. Box 2001, Oak Ridge, TN 37831.

30. R. Pederson, Idaho National Engineering and Environmental Laboratory, MS 3765, P.O. Box 1625, Idaho Falls, ID 83415-3765.

31. D. Peko, U.S. Department of Energy, 1000 Independence Avenue SW, Forrestal Building 6G-050, MS MD-3, Washington, DC 20585.

32. P. T. Rhoads, U.S. Department of Energy, MD-3, 1000 Independence Avenue SW, Forrestal Building 6G-050, Washington, DC 20585.

33. R. A. Roesener, Idaho National Engineering and Environmental Laboratory, MS 3765, P.O. Box 1625, Idaho Falls, ID 83415-3765.

34. M.D. Ruska, Manager, LMITCO Packaging and Transportation, Idaho National Engineering and Environmental Laboratory, MS 3765, P.O. Box 1625, Idaho Falls, ID 83415-4105. 
35-36. J. M. Ryskamp, Idaho National Engineering and Environmental Laboratory, MS 3885, P.O. Box 1625, Idaho Falls, ID 83415-3885.

37. R. H. Steele, MPR Associates Inc., 320 King Street, Alexandria, VA 22314-3238.

38. M. R. Taylor, DOE-ID Transportation Program Manager, Department of Energy, Idaho Operations, 850 Energy Drive, MS 1147, Idaho Falls, ID 83401-1563.

39. J. H. Thompson, U.S. Department of Energy, MD-3, 1000 Independence Avenue SW, Forrestal Building 6G-050, Washington, DC 20585. 